\title{
Taxonomic groups with lower movement capacity may present higher beta diversity
}

\author{
Vinícius X. da Silva' ${ }^{1}$ Mario Sacramento ${ }^{1,2}$, Érica Hasui' ${ }^{1}$ Rogério G. T. da Cunha' \& Flavio N. Ramos ${ }^{1}$ \\ 1. Laboratório de Ecologia de Fragmentos Florestais, Instituto de Ciências da Natureza, Universidade Federal de Alfenas, Rua Gabriel Monteiro da Silva, 700, Centro,
37130-000 Alfenas, MG, Brazil. (vxsilva@gmail.com) \\ 2. Estação de Hidrobiologia e Piscicultura de Furnas, Rua Lavras, 288, 37947-000 São José da Barra, MG, Brazil.
}

Received 4 February 2016.

Accepted 19 July 2016.

DOI: $10.1590 / 1678-4766 e 2017005$

\begin{abstract}
Diversity analysis by partition is an approach employed in order to understand how communities spatially structure themselves and the factors that operate in the generation and maintenance of distribution patterns. We examined the spatial structure of species diversity of four taxonomic groups, with different dispersal abilities, in 16 forest fragments in the southern region of the state of Minas Gerais, Brazil. Specifically, we tested: i) if the similarity in species composition would be negatively related to geographical distance between the 16 fragments; and ii) if the beta diversity of the different groups could be negatively related to their dispersal abilities. Alpha diversity and the compositional similarity between localities were both low. Beta diversity was not correlated with distance for any of the groups. Primates, followed by birds, showed a higher tendency of forming similarity groupings, although in a manner that was independent from distance between fragments, as well as showed the lowest beta diversity relative values. Spermatophytes and amphibians did not define groupings and presented the highest values of beta diversity. We interpreted such results as indications that the groups with higher dispersal ability (primates and birds) tend to reach, on average, farther localities and, therefore, to define more similar groupings (low beta diversity). The groups with lower dispersal ability (spermatophytes and amphibians) showed the opposite tendency. Although most of the species were restricted to few localities, contributing to the low similarity, beta and gamma diversity values showed the extent which the localities are, respectively, different and complementary to each other in terms of species composition. Such features reinforce and justify future conservation initiatives, both in local and regional levels.
\end{abstract}

KEYWORDS. Complementarity, dispersal ability, vertebrates, spermatophytes, Atlantic Forest.

RESUMO. Grupos taxonômicos com menor capacidade de dispersão podem apresentar maior diversidade beta. A análise da diversidade por partição é uma abordagem empregada para tentar compreender como as comunidades se estruturam espacialmente e os fatores que operam na geração e manutenção dos padrões de distribuição das espécies. Nós examinamos a estrutura espacial da diversidade de espécies referente a quatro grupos taxonômicos com diferentes capacidades de dispersão, em 16 fragmentos florestais localizados no sul do Estado de Minas Gerais, Brasil. Especificamente, testamos: i) se a similaridade na composição de espécies estaria relacionada negativamente com a distância geográfica entre os fragmentos e ii) se a diversidade beta apresentada por cada grupo poderia ser negativamente relacionada com as respectivas capacidades de dispersão. Tanto a diversidade alfa quanto a similaridade composicional entre as localidades foram baixas. A diversidade beta não esteve correlacionada com a distância para nenhum dos grupos. Os primatas, seguidos das aves, apresentaram maior tendência em formar agrupamentos de similaridade, embora de maneira independente da distância entre os fragmentos, bem como os menores valores relativos de diversidade beta. Já espermatófitas e anfíbios não definiram agrupamentos e apresentaram relativamente os maiores valores de diversidade beta. Interpretamos tais resultados como indicações de que grupos com maior capacidade de dispersão (primatas e aves) tendem a alcançar, em média, localidades mais distantes e, portanto, a definir agrupamentos mais similares (i.e. baixa diversidade beta). Já os grupos com menor capacidade de dispersão (espermatófitas e anfíbios) apresentaram a tendência oposta. Apesar da maioria das espécies terem apresentado ocorrência restrita a poucas localidades, contribuindo para a baixa similaridade, as altas diversidades beta e gama demonstraram o quanto as localidades são distintas e complementares entre si em termos de composição de espécies. Tais características reforçam e justificam futuras iniciativas de conservação, tanto em âmbito local quanto regional.

PALAVRAS-CHAVE. Complementariedade, habilidade de dispersão, vertebrados, espermatófitas, Mata Atlântica.

Several factors contribute to the diversity structure in communities and such factors are usually scale-dependent and interact with ecological, evolutionary and biogeographical processes (RickleFs, 1987; Pineda \& HalfFTER, 2004; GARDNER et al., 2009). Species diversity in an area can also be considered at different scales, and can be split into alpha, beta and gamma components (WHITTAKER, 1960, 1972). Alpha diversity corresponds to the species richness found in a location or individual habitat (WHITTAKER, 1960), which constitutes the sampling unit that contains an assemblage or community. Beta diversity, on the other hand, describes how the species composition varies in time and/or space between habitats/units (WHITTAKER, 1960, 1972; KOLEFF et al., 2003; Anderson et al., 2010). Gamma diversity is the entire species diversity observed in an area, landscape or region that contains a certain set of sampling units (WHITTAKER, 


\section{0; Tuomisto, 2010).}

Beta diversity thus relates the alpha to the gamma diversity (RICKLEFS, 1987; ANDERSON et al., 2010), indicating how many species are shared between the habitats/units and, therefore, the degree of biotic heterogeneity of a region (WILSON \& SHMIDA, 1984). Beta diversity may be positively associated with environmental heterogeneity (SOININEN et al., 2007a) or be independent from it, varying only with space (HuBbel, 2001).

Several factors may influence spatial variation in beta diversity, such as geographical, environmental, historical and evolutionary processes (SoININEN et al., 2007a). Those processes normally produce an inverse relationship between similarity in species composition and geographical distance among sampling units (NeKOLA \& White, 1999; HubBel, 2001). Such relation is partially due to the spatial autocorrelation pattern of environmental variables, with closer locations tending to be more environmentally similar to each other (LEGENDRE, 1993), which, by itself, influences the composition of species communities (HARRISON et al., 1992; JiMÉNEZ-VALVERDE et al., 2010). Therefore, a decrease in the similarity of environmental conditions along space may result in a correspondent decrease of the similarity in species composition (STEINITZ et al., 2006).

Among the biotic factors that may influence the pattern of beta diversity there are the life history of the species (SOININEN et al., 2007a) and the organisms' dispersal ability (DoBrovolski et al., 2011). Also, taxonomic groups of organisms may be broadly categorized in a gradient according to their dispersal abilities. Thus, the decay of similarity with the increase of geographical distance would be relatively higher for taxonomic groups that show lower dispersal ability (SOININEN et al., 2007b; QIAN 2009a; DobrovOLSKI et al., 2011). Spermatophytes usually have passive dispersal and depend on seed dispersal agents (e.g. TABARELLI \& Peres, 2002; Almeida-Neto et al., 2008). Among terrestrial vertebrates, birds are the most vagile, followed by mammals, amphibians being the less mobile ones (BöHNING-GAESE et al., 1998; QIAN, 2009b; Dobrovolski et al., 2011; QIAN \& RICKLEFS, 2012).

In disturbed landscapes, one of the factors that may influence changes in beta diversity in relation to conserved habitats also relates to different dispersal abilities. Since fragmentation generates barriers for movement, it may limit even more the dispersal ability of organisms and, thus, favor differentiation in composition among fragments (ARROYORODRÍGUEZ et al., 2013). Following the pattern expected for undisturbed landscapes, groups with high dispersal ability would thus have bigger chances of (re)colonizing neighbor habitats, keeping viable populations and reducing, that way, the compositional differences between fragments, the opposite occurring in groups with lower movement capacities (SOININEN et al., 2007a).

In this study we analyzed the beta diversity variation of four groups with different dispersal abilities (spermatophytes, amphibians, birds and primates) in a region of the Atlantic Forest hotspot (MYERs et al., 2000), a highly fragmented biome. Specifically, our aims were: 1- to evaluate the relative contributions of alpha and beta diversities to the gamma diversity; 2- to test if there is higher similarity between closer localities than between farther ones due to spatial autocorrelation (LEGENDRE, 1993; JIMÉNEZ-VALVERDE et al., 2010), especially regarding groups with relatively higher dispersal ability (birds and primates) (BUCKLEY \& JETZ, 2008; QIAN \& RiCKLEFS, 2012); and 3- to test whether beta diversity is higher in groups with lower dispersal capacity. A better understanding of these issues will allow taking more scientifically sound decisions for the management and conservation of these fragments, especially in a biome as threatened as the Atlantic Rainforest (PINTO et al., 2006). For example, understanding the contribution of the complementarity (beta diversity) to the gamma diversity within a landscape is important to the SLOSS debate and to where we should aim our conservation efforts (MARGULES $\&$ PRESSEY, 2000). In addition, understanding the influence of the dispersal capacity on the beta diversity may help us to take management decisions fine-tuned to specific issues of the different groups.

\section{MATERIAL AND METHODS}

Study sites. We conducted rapid surveys of spermatophytes, birds, amphibians and primates in 16 forest fragments in the southern region of the state of Minas Gerais, Brazil (Fig. 1, Tab. I), covering an area of about $65,000 \mathrm{~km}^{2}$, during the summers of 2010 and 2011. Most of the fragments are located in areas listed as priorities for conservation (sensu Drummond et al., 2005, see green areas on the map). We employed a rapid survey approach, sampling each fragment once during two consecutive days (e.g. Herzog et al., 2002; Young et al., 2003; Penter et al., 2008).

Sampling. We recorded the occurrence of species using complementary methods, which increases the chances of sampling a greater number of species in a short period of time (SilveIra et al., 2010).

For spermatophytes, we used the quadrant point's method (CоTTAm \& CuRTis, 1956), sampling 20 points on each fragment. The points were placed roughly $20 \mathrm{~m}$ apart from each other along a $400 \mathrm{~m}$ transect in the central region of the fragment. In each point, we recorded the closest four individuals with diameter at breast height $(\mathrm{DBH}) \geq$ $3 \mathrm{~cm}$. We identified the plants through comparisons with herbarium specimens and consultations with specialists and the specialized literature. We deposited the exsiccates in the herbarium of the Universidade Federal de Alfenas (UALF). Species nomenclature followed APG III (ANGIOSPERM Phylogeny Group, 2009).

For amphibians, we employed visual and audio surveys (CRUMP \& SCOTT JR., 1994) during a fixed time period (between $19 \mathrm{~h} 00 \mathrm{~min}$ and $00 \mathrm{~h} 00 \mathrm{~min}$ ). The search for individuals was directed to breeding sites, especially water bodies (SCOTT JR. \& WoodWARD, 1994), as well as leaf litter and vegetation along trails and transects made to access the breeding sites. The sampling effort was 20 hours- 


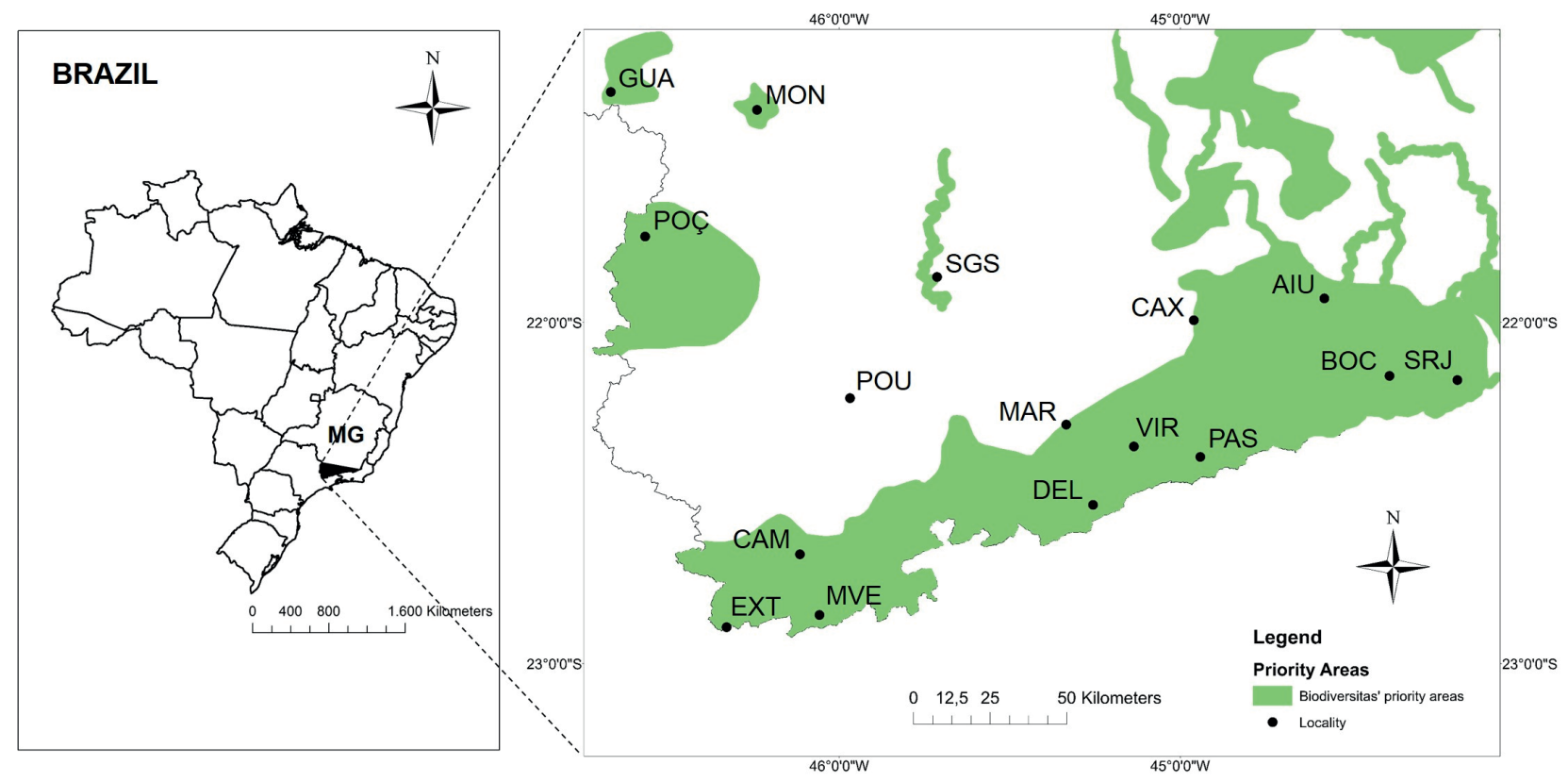

Fig. 1. Location of the 16 fragments sampled in Minas Gerais, Brazil (LOCALITY, municipality): AIU, Aiuruoca; BOC, Bocaina de Minas; CAM, Camanducaia; CAX, Caxambu; DEL, Delfim Moreira; EXT, Extrema; GUA, Guaxupé; MAR, Maria da Fé; MON, Monte Belo; MVE, Monte Verde; PAS, Passa Quatro; POÇ, Poços de Caldas; POU, Pouso Alegre; SGS, São Gonçalo do Sapucaí; SRJ, Santa Rita de Jacutinga and VIR, Virgínia.

Tab. I. Main characteristics of the 16 fragments sampled in Minas Gerais, Brazil (biome; geographic coordinates; area; altitude) and respective sampling period (month and year) (AIU, Aiuruoca; BOC, Bocaina de Minas; CAM, Camanducaia; CAX, Caxambu; DEL, Delfim Moreira; EXT, Extrema; GUA, Guaxupé; MAR, Maria da Fé; MON, Monte Belo; MVE, Monte Verde; PAS, Passa Quatro; POÇ, Poços de Caldas; POU, Pouso Alegre; SGS, São Gonçalo do Sapucaí; SRJ, Santa Rita de Jacutinga; VIR, Virgínia).

\begin{tabular}{|c|c|c|c|c|c|}
\hline Locality & Biome & Coordinates & Area (ha) & Altitude (m) & Month/Year \\
\hline AIU & SSF & $21^{\circ} 55^{\prime} 46^{\prime \prime} \mathrm{S}, 44^{\circ} 34^{\prime} 54^{\prime \prime} \mathrm{W}$ & 225 & 1056 & Feb./2011 \\
\hline $\mathrm{BOC}$ & OF & $22^{\circ} 09^{\prime} 22^{\prime \prime} \mathrm{S}, 44^{\circ} 22^{\prime} 57^{\prime \prime} \mathrm{W}$ & 41 & 1263 & Feb./2011 \\
\hline CAM & SSF & $22^{\circ} 40^{\prime} 50^{\prime \prime} \mathrm{S}, 46^{\circ} 06^{\prime} 55^{\prime \prime} \mathrm{W}$ & 72 & 1132 & Dec./2010 \\
\hline CAX & SSF & $21^{\circ} 59^{\prime} 39^{\prime \prime} \mathrm{S}, 44^{\circ} 57^{\prime} 46^{\prime \prime} \mathrm{W}$ & 176 & 1037 & Jan./2011 \\
\hline DEL & OF & $22^{\circ} 31^{\prime} 32^{\prime \prime} \mathrm{S}, 45^{\circ} 14^{\prime} 07^{\prime \prime} \mathrm{W}$ & 1591 & 1372 & Dec./2010 \\
\hline EXT & OF & $22^{\circ} 53^{\prime} 41^{\prime \prime} \mathrm{S}, 46^{\circ} 19^{\prime} 25^{\prime \prime} \mathrm{W}$ & 4112 & 1539 & Dec./2010 \\
\hline GUA & SSF & $21^{\circ} 20^{\prime} 06^{\prime \prime} \mathrm{S}, 46^{\circ} 39^{\prime} 54^{\prime \prime} \mathrm{W}$ & 763 & 1012 & Feb./2010 \\
\hline MAR & SSF & $22^{\circ} 16^{\prime} 28^{\prime \prime} \mathrm{S}, 45^{\circ} 22^{\prime} 25^{\prime \prime} \mathrm{W}$ & 192 & 1566 & Jan./2011 \\
\hline MVE & OF & $22^{\circ} 52^{\prime} 08^{\prime \prime} \mathrm{S}, 45^{\circ} 58^{\prime} 13^{\prime \prime} \mathrm{W}$ & 7143 & 1585 & Dec./2010 \\
\hline MON & SSF & $21^{\circ} 22^{\prime} 07^{\prime \prime} \mathrm{S}, 46^{\circ} 16^{\prime} 44^{\prime \prime} \mathrm{W}$ & 525 & 865 & Feb./2010 \\
\hline PAS & $\mathrm{OF}$ & $22^{\circ} 23^{\prime} 30^{\prime \prime} \mathrm{S}, 44^{\circ} 56^{\prime} 28^{\prime \prime} \mathrm{W}$ & 459 & 1114 & Jan./2011 \\
\hline POÇ & SSF & $21^{\circ} 54^{\prime} 17^{\prime \prime} \mathrm{S}, 46^{\circ} 32^{\prime} 15^{\prime \prime} \mathrm{W}$ & 36 & 1427 & Feb./2010 \\
\hline POU & SSF & $22^{\circ} 13^{\prime} 21^{\prime \prime} \mathrm{S}, 45^{\circ} 58^{\prime} 02^{\prime \prime} \mathrm{W}$ & 358 & 907 & Dec./2010 \\
\hline SGS & SSF & $21^{\circ} 52^{\prime} 40^{\prime \prime} \mathrm{S}, 45^{\circ} 36^{\prime} 40^{\prime \prime} \mathrm{W}$ & 25 & 1016 & Feb./2010 \\
\hline SRJ & $\mathrm{OF}$ & $22^{\circ} 10^{\prime} 02^{\prime \prime} \mathrm{S}, 44^{\circ} 10^{\prime} 59^{\prime \prime} \mathrm{W}$ & 438 & 719 & Feb./2011 \\
\hline VIR & OF & $22^{\circ} 19^{\prime} 16^{\prime \prime} \mathrm{S}, 45^{\circ} 09^{\prime} 45^{\prime \prime} \mathrm{W}$ & 2083 & 1650 & Jan./2011 \\
\hline
\end{tabular}

man per locality. Some voucher specimens (AURICCHIO \& SALOMÃo, 2002) were deposited in the Coleção Herpetológica Alfred Russel Wallace (CHARW) of Universidade Federal de Alfenas (IBAMA license \#10704-1).

For birds, we employed the capture of understory species with mist nets ( $12 \mathrm{~m} \times 2.5 \mathrm{~m} \times 31 \mathrm{~mm}$ mesh) (Develey, 2003). We installed ten nets in a row along a $150 \mathrm{~m}$ transect inside the forest, at least $50 \mathrm{~m}$ distant from the edge. The nets remained opened between $07 \mathrm{~h} 00 \mathrm{~min}$ and $17 \mathrm{~h} 00 \mathrm{~min}$, totaling 200 net-hours effort per location. Each captured individual was identified and subsequently released (IBAMA license \#22020-1).

For the primate surveys, we employed a couple of different approaches. To attempt detecting the buffy-tufted- ear marmosets, Callithrix aurita (E. Geoffroy in Humboldt, 1812), the black-fronted titi monkeys, Callicebus nigrifrons (Spix, 1823), and the brown tufted capuchin monkeys, Sapajus nigritus Goldfuss, 1809, we used playbacks. We selected long-range, high amplitude calls, which are proposed to function either in inter-group communication (marmoset long calls and titi monkey duets) or to maintain contact between group members (capuchin monkey whistles). We reproduced the same calls throughout the study, both within the forest and/or at the borders. Inside the fragments we played the calls up to four times at different directions in each sampling point, so as to attempt covering a $360^{\circ}$ radius around it. In contrast, we reproduced calls in two directions at the forest borders (each $45^{\circ}$ from the edge line). Playbacks 
for a given species were ended as soon as a response was obtained. Some occurrences were also recorded through direct visual and auditory contact (RosALES-MEDA, 2007). In addition, we interviewed landowners and residents near the fragments about the occurrence of species (WATERS \& ULLOA, 2007). This procedure was necessary to verify the occurrence of Alouatta guariba clamitans Cabrera, 1940, which usually do not respond well to playbacks. Also, marmosets and capuchins are less responsive to playbacks than titi monkeys, and are more likely not to respond, even if present. If the respondent mentioned the occurrence of marmosets, we only included these data if we could locate and identify the species, given the occurrence of an exotic species of the genus, Callithrix penicillata (E. Geoffroy, 1812), in the region. The fragment was excluded from further analysis if we could not correctly identify the species. In Pouso Alegre and Passa Quatro localities, we also obtained information regarding the presence of primates through management plans of the protected areas we surveyed. Given the lower richness of this group, we did not restrict ourselves to the two-day sampling scheme. When we had indications that a species might occur in a locality (e.g. through interviews), but were unsure about it (for example of which marmoset species it were, or due to conflicting or apparently inaccurate reports), we returned to the fragments in other occasions in a further attempt to confirm the findings. Whenever in doubt, we did not consider a species as occurring in a fragment.

Data analysis. Herein we considered gamma diversity $(\gamma)$ as the total number of registered species in the 16 fragments sampled (regional richness, but see TuOMisto, $2010)$. We considered alpha diversity $(\alpha)$ to be the number of species in each fragment (local richness). Last, we defined beta diversity $(\beta)$ as the non-directional variation on species composition between the fragments (sensu ANDERSON et al., 2010). We calculated beta diversity in two ways, using three different measures $\left(\beta_{\mathrm{W}} ; \beta_{\text {add }} ; \beta_{\mathrm{C}}\right)$ :

(1) Variation on the number of species among the localities: here we used both multiplicative beta diversity $\left(\beta_{\mathrm{W}}\right)$ (WhitTAKer, 1960) and additive beta diversity $\left(\beta_{\text {add }}\right)$ (LANDE, 1996; Crist \& VeECH, 2006) measures. The multiplicative beta diversity is given by the formula $\left[\beta_{\mathrm{w}}=\gamma / \alpha_{\text {mean }}\right]$, where $\gamma$ is the total number of species for the region and $\alpha_{\text {mean }}$ is the average number of species of the 16 fragments. $\beta_{\mathrm{w}}$ thus indicates "the number of times by which the richness in a region is greater than the average richness in the smallerscale units" (ANDERSON et al., 2010). On the other hand, the additive beta diversity is given by the formula $\left[\beta_{\text {add }}=\right.$ $\left.\gamma-\alpha_{\text {mean }}\right]$ and it informs the average number of species that are not shared among all the sampling units (ANDERSON et al., 2010).

(2) Variation on the species composition between localities: beta diversity as a measure of complementarity $\left(\beta_{\mathrm{C}}\right)$. Through paired comparison of species between localities, the proportion of species that occur in only one of those localities is evaluated in relation to the total number species of both localities (COLWELL \& CoDDINGTON, 1994). The beta diversity values, in this case, are represented by the inverse of the similarity indexes of species' values (see next paragraph), that is, $\left[\beta_{\mathrm{C}}=1-\mathrm{Cj}\right]$, where $\mathrm{Cj}$ is the similarity index value (KREBS, 1999). Thereby, pairs of locations with low similarity in species composition show high beta diversity, and vice versa. Complementarity values vary from zero (identical species composition between two localities) to 1 (completely different species composition between two localities) (COLWELl \& CoDdington, 1994). We considered the values of average complementarity as significant if $\beta_{\mathrm{C}}$ was $\geq 0.5$ (50\%) (VASCONCELOS et al., 2011).

Similarity in species composition was quantified both for each taxonomic group and for the four groups combined through grouping or cluster analysis (UPGMA) and computation of the Jaccard's similarity index $(\mathrm{Cj})$ (MagurRan, 1988), which determines the proportion of species shared between each pair of localities. We considered as a grouping every pair or group of localities showing $\mathrm{Cj} \geq$ 0.5 . To verify if there was any correlation between species composition similarity and geodesic geographical distance between the localities, we applied the Mantel test (LEGENDRE \& LEGENDRE, 2012), whose $r$ values may vary from -1 (strong negative correlation) to +1 (strong positive correlation), zero meaning absence of correlation. The tests were carried out in the program $\mathrm{R}$, version 3.0.1. (R Development CoRE TEAM, 2013).

Last, to classify the species according to the frequency of occurrence in the 16 localities, we used the following categories (adapted from DAJOZ, 1983): "frequent" (species with registered presence in at least nine locations); "common" (occurrence in five to eight locations); and "rare" (occurrence in four locations or less). Both the exotic species and the ones recorded by chance (i.e. outside the standardized sampling methods) were not computed on the data analysis. However, we included them in the general relation of species described in the supplementary material (Appendixes 1 to 4).

\section{RESULTS}

We found 259 species of spermatophytes (Appendix 1), 45 of amphibians (Appendix 2), 66 of birds (Appendix 3) and four of primates (Appendix 4). However, local richness was usually much smaller than that (Tab. II). We also registered one exotic anuran species Lithobates catesbeianus (Shaw, 1802) in Delfim Moreira and one introduced primate species Callithrix penicillata in Guaxupé, Caxambu, Aiuruoca, Passa Quatro and Bocaina de Minas. The list of all species we recorded, as well as their distributions along the 16 fragments and respective frequency of occurrence (FO) can be found in the supplementary material (Appendixes 1 to 4 ).

Through the multiplicative beta diversity measure $\left(\beta_{\mathrm{w}}\right)$, we verified that there were 8.3 times more species of spermatophytes, 5.3 times more amphibians, 3.2 times more birds' species and 1.7 times more primate species on the regional scale $(\gamma)$ than in each locality $(\alpha)$. Through the additive beta diversity measure $\left(\beta_{\text {add }}\right)$, we verified that the proportion of species that are not shared among all localities was of 228 spermatophytes, 36 amphibians, 46 birds and two 
Tab. II. Local species richness (alpha diversity) of spermatophytes, amphibians, birds, primates and all the groups found in the 16 fragments sampled in Minas Gerais, Brazil (AIU, Aiuruoca; BOC, Bocaina de Minas; CAM, Camanducaia; CAX, Caxambu; DEL, Delfim Moreira; EXT, Extrema; GUA, Guaxupé; MAR, Maria da Fé; MON, Monte Belo; MVE, Monte Verde; PAS, Passa Quatro; POÇ, Poços de Caldas; POU, Pouso Alegre; SGS, São Gonçalo do Sapucaí; SRJ, Santa Rita de Jacutinga; VIR, Virgínia).

\begin{tabular}{|c|c|c|c|c|c|}
\hline Locality & Spermatophytes & Amphibians & Birds & Primates & All \\
\hline AIU & 38 & 7 & 23 & 2 & 70 \\
\hline $\mathrm{BOC}$ & 29 & 9 & 13 & 2 & 54 \\
\hline CAM & 34 & 6 & 13 & 1 & 54 \\
\hline CAX & 34 & 10 & 14 & 3 & 61 \\
\hline DEL & 35 & 15 & 22 & 3 & 75 \\
\hline EXT & 39 & 9 & 22 & 3 & 73 \\
\hline GUA & 27 & 6 & 26 & 2 & 61 \\
\hline MON & 23 & 8 & 21 & 2 & 54 \\
\hline MAR & 22 & 9 & 21 & 2 & 54 \\
\hline MVE & 31 & 9 & 19 & 2 & 61 \\
\hline PAS & 26 & 10 & 23 & 3 & 62 \\
\hline POÇ & 37 & 8 & 23 & 2 & 70 \\
\hline POU & 28 & 5 & 29 & 4 & 66 \\
\hline SGS & 27 & 3 & 20 & 1 & 51 \\
\hline SRJ & 31 & 11 & 19 & 3 & 64 \\
\hline VIR & 36 & 9 & 16 & 2 & 63 \\
\hline mean \pm sd & $31.1 \pm 5.3$ & $8.4 \pm 2.7$ & $20.3 \pm 4.5$ & $2.3 \pm 0.8$ & $62.1 \pm 7.4$ \\
\hline
\end{tabular}

primate species. The distinction between species composition $\left(\beta_{\mathrm{C}}\right)$ between pairs of locations was, on average, significant for spermatophytes $(0.92$; range: $0.75-1)$, amphibians $(0.83$; range: $0.47-1)$, birds (0.68; range: $0.42-0.91)$ and all the groups together ( 0.83 ; range: $0.69-0.93)$, but not for primates (0.47; range: $0-0.75)$.

As for the frequency of occurrence within the set of fragments, most of the species (84.4\%) were "rare" when we consider the four groups combined, occurring in only one, two, three or four localities. The same pattern was observed for spermatophytes (93.8\%), amphibians (77.3\%) and birds (57.6\%), but not for primates ( $0 \%$ ) (Fig. 2).

When we analyzed the species composition similarity, there was no grouping between localities regarding spermatophytes (Fig. 3). As for the amphibians (Fig. 4), there was only the MAR-DEL grouping, with both localities
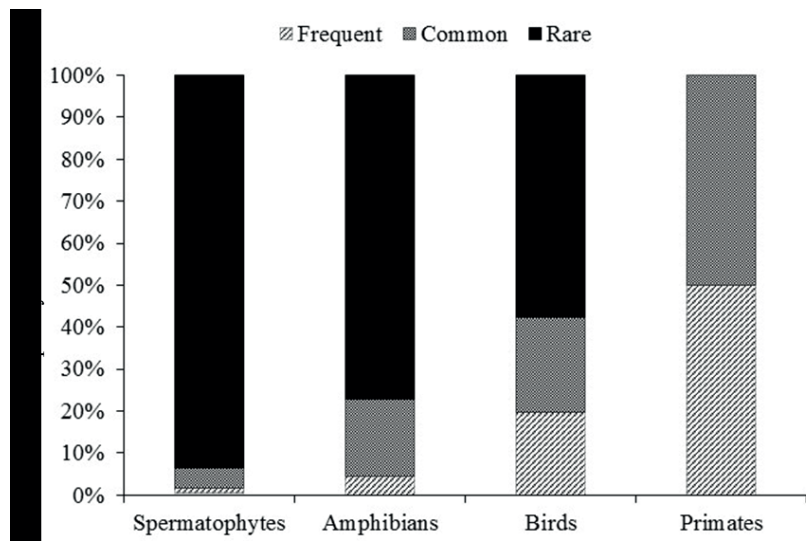

Fig. 2. Frequency of occurrence of spermatophytes $(\mathrm{n}=259)$, amphibians $(\mathrm{n}=44)$, birds $(\mathrm{n}=66)$ and primates $(\mathrm{n}=4)$ species in the 16 localities sampled in Minas Gerais, Brazil. Frequent (species with registered presence between nine and 16 locations); common (between five and eight localities); and rare (between one and four localities). showing the same type of phytophysiognomy (ombrophilous forest), but located $117 \mathrm{~km}$ apart from each other (Fig. 1). In birds, four groupings of similarity were formed (Fig. 5). The localities from the groupings POU-MAR and MONGUA showed the same phytophysiognomy (seasonal semideciduous forest) and are relatively close to each other (61 and $40 \mathrm{~km}$, respectively). However, the localities of the groupings EXT-SRJ and MVE-DEL, though presenting the same phytophysiognomy of ombrophilous forest, are distant from each other 235 and $90 \mathrm{~km}$, respectively. The primates grouping (Fig. 6) was the only one with high composition similarity, forming six locality groupings, with all of them showing the same phytophysiognomy between the fragments

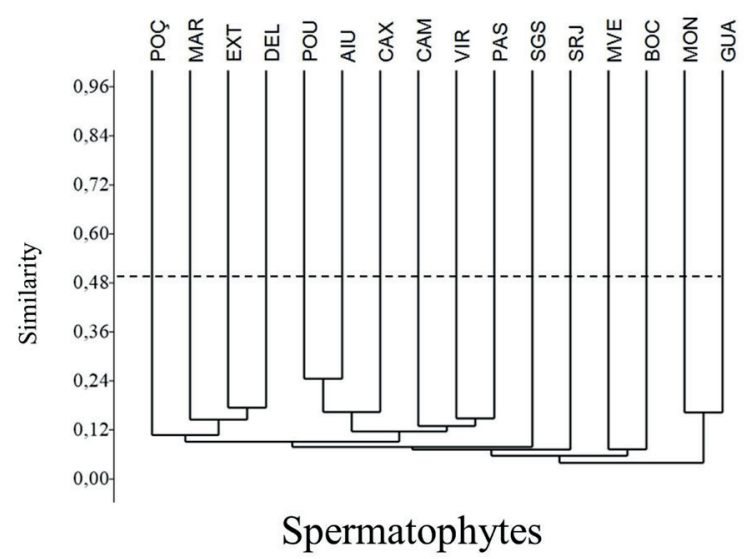

Fig. 3. Similarity in species composition of spermatophytes among the 16 localities sampled in Minas Gerais, Brazil, based on the Jaccard coefficient of similarity and subsequent cluster analysis (UPGMA). Obs.: dashed line (significance level: 0.5 or $50 \%$ ) (AIU, Aiuruoca; BOC, Bocaina de Minas; CAM, Camanducaia; CAX, Caxambu; DEL, Delfim Moreira; EXT, Extrema; GUA, Guaxupé; MAR, Maria da Fé; MON, Monte Belo; MVE, Monte Verde; PAS, Passa Quatro; POÇ, Poços de Caldas; POU, Pouso Alegre; SGS, São Gonçalo do Sapucaí; SRJ, Santa Rita de Jacutinga; VIR, Virgínia). 
of each grouping, independently from geographical distance. The only grouping common to birds and primates was MONGUA. We did not find any grouping when we analyzed the four groups simultaneously (Fig. 7). Finally, we did not find any relation between species composition and geographical distance between localities for any of the groups through the Mantel test: spermatophytes $(\mathrm{r}=0.03, \mathrm{p}=0.35)$, amphibians $(\mathrm{r}=-0.01, \mathrm{p}=0.5)$, birds $(\mathrm{r}=-0.006, \mathrm{p}=0.49)$, primates $(\mathrm{r}=0.14, \mathrm{p}=0.072)$, and all the four groups together $(\mathrm{r}=$ $0.01, \mathrm{p}=0.45)$.

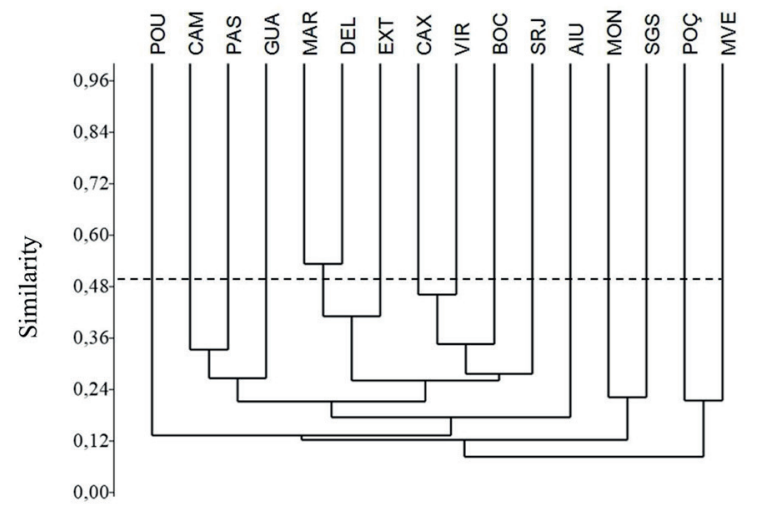

Amphibians

Fig. 4. Similarity in species composition of amphibians among the 16 localities sampled in Minas Gerais, Brazil, based on the Jaccard coefficient of similarity and subsequent cluster analysis (UPGMA). Obs.: dashed line (significance level: 0.5 or $50 \%$ ) (AIU, Aiuruoca; BOC, Bocaina de Minas; CAM, Camanducaia; CAX, Caxambu; DEL, Delfim Moreira; EXT, Extrema; GUA, Guaxupé; MAR, Maria da Fé; MON, Monte Belo; MVE, Monte Verde; PAS, Passa Quatro; POÇ, Poços de Caldas; POU, Pouso Alegre; SGS, São Gonçalo do Sapucaí; SRJ, Santa Rita de Jacutinga; VIR, Virgínia).

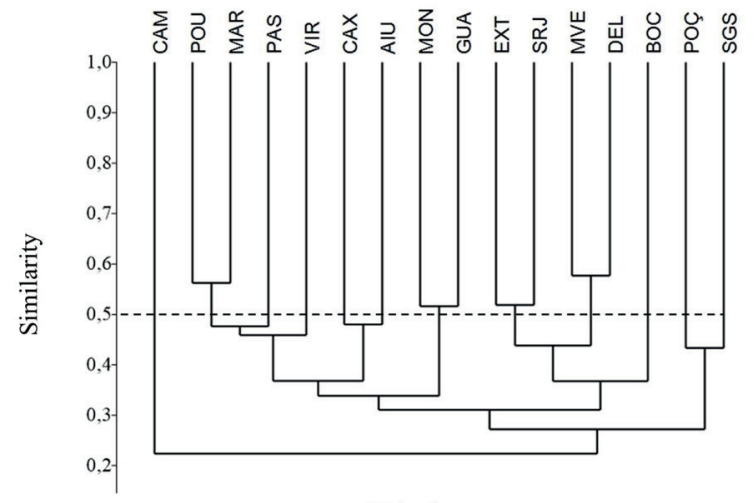

Birds

Fig. 5. Similarity in species composition of birds among the 16 localities sampled in Minas Gerais, Brazil, based on the Jaccard coefficient of similarity and subsequent cluster analysis (UPGMA). Obs.: dashed line (significance level: 0.5 or 50\%) (AIU, Aiuruoca; BOC, Bocaina de Minas; CAM, Camanducaia; CAX, Caxambu; DEL, Delfim Moreira; EXT, Extrema; GUA, Guaxupé; MAR, Maria da Fé; MON, Monte Belo; MVE, Monte Verde; PAS, Passa Quatro; POÇ, Poços de Caldas; POU, Pouso Alegre; SGS, São Gonçalo do Sapucaí; SRJ, Santa Rita de Jacutinga; VIR, Virgínia).

\section{DISCUSSION}

Beta diversity showed no correlation with geographic distance. Primates, followed by birds, presented a greater tendency to form location groups with species compositions more alike between themselves, though in a way that was independent from geographic distance, as well as showed the lower beta diversity values. On the other hand, spermatophytes and amphibians did not define such groupings and showed the highest values of beta diversity. We interpreted those

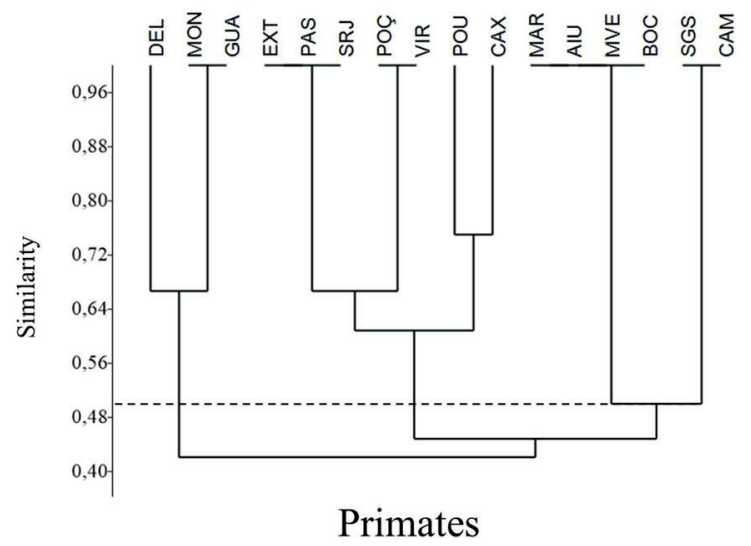

Fig. 6. Similarity in species composition of primates among the 16 localities sampled in Minas Gerais, Brazil, based on the Jaccard coefficient of similarity and subsequent cluster analysis (UPGMA). Obs.: dashed line (significance level: 0.5 or $50 \%$ ) (AIU, Aiuruoca; BOC, Bocaina de Minas; CAM, Camanducaia; CAX, Caxambu; DEL, Delfim Moreira; EXT, Extrema; GUA, Guaxupé; MAR, Maria da Fé; MON, Monte Belo; MVE, Monte Verde; PAS, Passa Quatro; POÇ, Poços de Caldas; POU, Pouso Alegre; SGS, São Gonçalo do Sapucaí; SRJ, Santa Rita de Jacutinga; VIR, Virgínia).

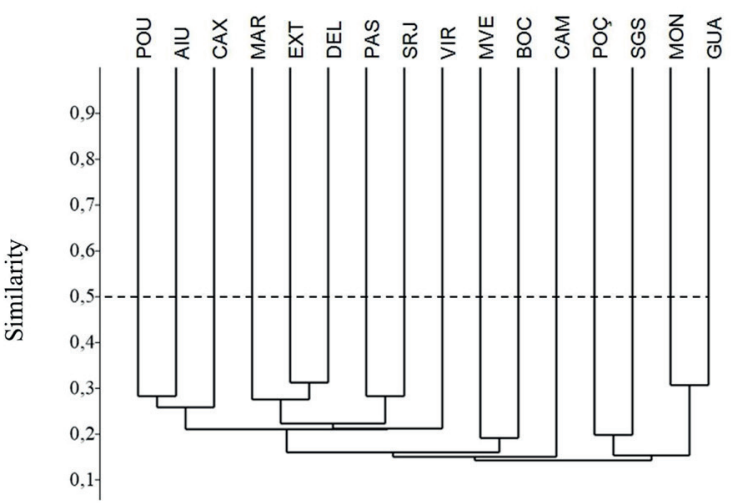

All

Fig. 7. Similarity in species composition of all the groups combined among the 16 localities sampled in Minas Gerais, Brazil, based on the Jaccard coefficient of similarity and subsequent cluster analysis (UPGMA). Obs.: dashed line (significance level: 0.5 or $50 \%$ ) (AIU, Aiuruoca; BOC, Bocaina de Minas; CAM, Camanducaia; CAX, Caxambu; DEL, Delfim Moreira; EXT, Extrema; GUA, Guaxupé; MAR, Maria da Fé; MON, Monte Belo; MVE, Monte Verde; PAS, Passa Quatro; POÇ, Poços de Caldas; POU, Pouso Alegre; SGS, São Gonçalo do Sapucaí; SRJ, Santa Rita de Jacutinga; VIR, Virgínia). 
results as indications that the groups with higher dispersal ability (primates and birds) reached, in average, more distant locations and tend, therefore, to define locality groups with more similar compositions (i.e. low beta diversity). In less vagile groups (spermatophytes and amphibians), the low dispersal ability does not favor them in occupying nearest locations, even if the ecological conditions allow; such groups, thus, present the reverse tendency of not forming locality groups with similar compositions (i.e. high beta diversity).

Primates, moreover, were the only group in which there were no species with "rare" frequency of occurrence, probably due to the low regional richness of only four species. This may have increased the probability of generating locality groupings with similar compositions by chance alone. By excluding this group, because of its exceedingly low species number, it is possible to conclude that beta diversity, be it of spermatophytes, amphibians, birds or all these groups together, exerted a greater influence on regional diversity (gamma) than local species richness (alpha) (PINEDA \& HALFFTER, 2004).

The absence of correlation between the similarity in species composition and the geographical distance and groupings of localities with similar compositions, independent from geographical distance, in birds and primates, suggests that other factors might be necessary to explain the variation on the species composition of each group along the space. Accordingly, several studies have demonstrated a host of different factors that may influence variation of species composition through space: (1) spatial and environmental gradients (e.g. Clark et al., 1999; NeKola \& White, 1999; Oliveira-Filho \& Fontes, 2000; CARneiro \& Valeriano, 2003; STEINITZ et al., 2006, 2007b; LEGENDRE et al., 2009); (2) differences in the physiology, in the degree of biological interactions and in the dispersal ability of the species (NeKola \& White, 1999; TuOmisto et al., 2003; Gilbert \& LECHOWICZ, 2004); (3) barriers imposed by the configuration of the landscape and the influence of weather on species' dispersion (Nekola \& White, 1999; HubBel, 2001); (4) stochastic processes generated randomly and independently of environmental dissimilarities (Neutral Theory sensu HuBBEL, 2001; SOININEN et al., 2007b; STEINBAUER et al., 2012); (5) species' tolerance to fragmentation (ARROYO-RODRÍGUEZ et al., 2013); (6) spatial scale (extension, resolution; NeKolA \& White, 1999; Steinitz et al., 2006; Soininen et al., 2007b; ARROYO-RoDríGUEZ et al., 2013). Therefore, more accurate analysis involving other variables could yield further explanations regarding the spatial distribution observed in this study.

Although our results support the relationship between dispersal ability and beta diversity, there are some controversial results in the literature (McKNIGHT et al., 2007). SoININEN et al. (2007a), for example, when comparing different trophic levels, showed that autotrophs have smaller beta diversity than omnivores and carnivores. This particular result was very different from ours, since the spermatophytes from our study showed a higher average beta diversity value than all other groups, constituted by animals. A possible explanation for these differences can be found in the suggestions by the same authors (SoININEN et al., 2007a): beta diversity is something very complex and influenced by extrinsic (e.g. landscape structure and environmental variations) and intrinsic factors (e.g. peculiar features of the organisms).

On the other hand, Qian (2009a) and ArroyoRoDRíGUEZ et al. (2013), both working with plants, showed results that were similar to those we found here, that is, high negative correlation between the dispersal ability and the beta diversity. According to ArRoyo-RodríGuez et al. (2013), increasing the distance between forest fragments leads to communities with very specific compositions (i.e. high beta diversity), given seed dispersal is limited. Such parallel may indicate a potential problem for the landscapes in southern Minas Gerais, given its high degree of fragmentation, which may lead in the future to local extinctions.

Amphibians showed a very similar result to the spermatophytes, only with slightly lower beta diversity values and much smaller gamma diversity (regional). The high beta diversity of the group can be explained by two factors. First we have amphibians strict environmental requirements (Duellman \& Trueb, 1994; Werner et al., 2007; Buckley \& JETZ, 2008), especially their need for both water (for reproduction), and higher temperatures, due to ectothermy (BuCKLEY \& JetZ, 2008; Qian, 2009b). Since the studied fragments vary in terms of water availability and altitude (thus temperature), the environmental requirements for amphibians vary accordingly. Besides, amphibians are usually considered as animals with low dispersal ability (QIAN, 2009b; DobRovolski et al., 2011; QIAN \& RicKLEFS, 2012). When compared to mammals and birds, amphibians always show higher beta diversity (see BUCKLEY \& JETZ, 2008; QIAN, 2009b; DobrovolsKi et al., 2011; QIAN \& RICKLEFS, 2012). The same was observed for reptiles, an equally ectothermic and little vagile group (see QIAN, 2009b; QIAN \& RICKLEFS, 2012). Amphibians may even show turnover values four times higher than birds (BUCKLEY \& JETZ, 2008). The opposite happens to the median size of the geographic distributions of these two groups. In general, birds have occurrence areas four times bigger than amphibians, a clear sign of the greater dispersal ability made possible by flight. The relationship between these patterns is so outstanding that the amphibians' turnover has been proved to be a better predictor for the birds' turnover than the environmental variables (BUCKLEY \& JETZ, 2008).

The high percentage of spermatophytes, amphibians and birds species with "rare" occurrence in this study is a sign of the low number of species shared between the local communities, especially on the first two groups. Some of these rarities actually represent less abundant species under some degree of threat (see INTERNATIONAL UNION FOR CONSERVATION OF NATURE, 2013), and the register of their occurrence is important for conservation purposes on the respective sampled municipalities. The registers of geographical distribution expansions are equally important, 
as, for example, in the case of the amphibian Ischnocnema holti (Cochran, 1948) in the locality of Extrema, which extended its range to about $160 \mathrm{~km}$ southwest of its typical locality (see Da Costa et al., 2008; TARgino \& CARVALHOE-SILVA, 2008).

The exotic species we found deserve mention due to the negative impacts they cause. The anuran Lithobates catesbeianus, originally from North America, is commercially farmed as a food source. Due to negligence in their containment, they commonly end up escaping captivity and settling up populations in natural environments, where they may cause problems to the native communities (Вотн et al., 2011; Silva et al., 2011). The locality in which this species was collected constitutes a new register for the state of Minas Gerais. The primate Callithrix penicillata, a typical species of the Cerrado biome (MirAndA \& FARIA, 2001), was deliberately introduced in Atlantic Forest environments. Worse, it is a species with high adaptability and dispersion power, causing several impacts and possibly even hybridizing with native species of this biome (STEVENSON \& RYLANDS, 1988; AURICCHIO, 1995).

A potential criticism to our results relates to the rapid survey sampling scheme we have adopted here. Such sampling scheme may be regarded insufficient (LAWTON et al., 1998; STEINBAUER et al., 2012), a problem compounded by the different levels of detectability of each species (BouLINIER et al., 1998), given that the surveys were relatively fast. However, the overall conclusion would not be affected by a longer sampling on each location. Although alpha diversity values might increase on each fragment with higher sampling efforts, beta diversity would remain high. The reason is that longer sampling allows registering species that are rarer, which, however, naturally show a patchy distribution in the landscape, particularly in a fragmented one. Therefore, our sampling scheme was sufficient to gather the data necessary to provide the basis for our conclusions.

In summary, although alpha diversity within fragments was low, we found low similarity in species composition between localities (i.e. high beta diversity values), thus resulting in a high gamma diversity. Primates were the only group with average complementarity below $50 \%$. In addition, they presented a greater tendency (followed by birds) to form location groups with species compositions more alike between themselves, though in a way that was independent from geographic distance. Thus, the decreasing gradient of beta diversity observed [spermatophytes $(92 \%)>$ amphibians $(83 \%)>$ birds $(68 \%)>$ primates $(48 \%)]$ coupled with the results of the groupings, indicate that the taxa with higher dispersal ability (primates and birds) may have reached, in average, more distant locations and tend, therefore, to define locality groups with more similar compositions (i.e. low beta diversity).

Acknowledgments. This project was funded by Fundação de Amparo à Pesquisa do Estado de Minas Gerais (FAPEMIG, Program BIOTA MINAS, \#APQ 03549-09). We are grateful to Ana C. MonteiroLeonel, Dérik F. F. Rosa, Diego G. S. Pereira, Carina S. Barbosa, Mainara X. Jordani, Raiane F. Marques, Renato A. J. Gaiga and Rodolph C. Loyola for the support in fieldwork; Bruno R. Ribeiro, Diogo B. Provete, Marco T. P. Coelho, Maria J. dos S. Wisniewski, Michel V. Garey, Renato N. Feio and Renato S. Bérnils for the useful suggestions in the previous version of this manuscript. We are also thankful to the landowners and to the managers and employees of the Floresta Nacional de Passa Quatro (ICMBio), Parque Municipal de Pouso Alegre (IEF) and Instituto Sul Mineiro de Estudos e Conservação da Natureza (ISMECN) for the permission to access the fragments. We especially thank Universidade Federal de Alfenas (UNIFALMG) for the logistic support; and CAPES for the master's scholarship (\#1144826) to MS. Two anonymous referees provided insightful comments which greatly helped to improve the manuscript.

\section{REFERENCES}

Almeida-Neto, M.; Campassi, F.; Galetti, M.; Jordano, P. \& OliveiraFilho, A. 2008. Vertebrate dispersal syndromes along the Atlantic forest: broad-scale patterns and macroecological correlates. Global Ecology and Biogeography 17:503-513.

Anderson, M. J.; Crist, T. O.; Chase, J. M.; Vellend, M.; Inouye, B. D.; Freestone, A. L.; Sanders, N. J.; Cornell, H. V.; Comita, L. S.; Davies, K. F.; Harrison, S. P.; Kraft, N. J. B.; Stegen, J. C. \& Swenson, N. G. 2010. Navigating the multiple meanings of $\beta$ diversity: a roadmap for the practicing ecologist. Ecology Letters 2010:1-16.

Angiosperm Phylogeny Group - APG III. 2009. An update of the Angiosperm Phylogeny Group classification for the orders and families of flowering plants: APG III. Botanical Journal of the Linnean Society 161:105-121.

Arroyo-Rodríguez, V.; Rös, M.; Escobar, F.; Melo, F. P. L.; SAntos, B. A.; Tabarelli, M. \& Chazdon, R. 2013. Plant b-diversity in fragmented rain forests: testing floristic homogenization and differentiation hypotheses. Journal of Ecology 101:1449-1458.

AuricChIO, P. 1995. Primatas do Brasil. São Paulo: Terra Brasilis. 168p.

Auricchio, P. \& SAlomão, M. G. 2002. Técnicas de coleta e preparação de vertebrados para fins científicos e didáticos. Arujá, Instituto Pau Brasil de História Natural. 349p.

Böhning-Gaese, K.; GonzÁlez-Guzmán, L. I. \& Brown, J. H. 1998. Constraints on dispersal and the evolution of the avifauna of the Northern Hemisphere. Evolutionary Ecology 12:767-783.

Both, C.; Lingnau, R.; Santos-Jr., A.; Madalozzo, B.; Lima, L. P. \& Grant, T. 2011. Widespread occurrence of the american bullfrog, Lithobates catesbeianus (Shaw, 1802) (Anura: Ranidae). South American Journal of Herpetology 6(2):127-134.

Boulinier, T.; Nichols, J. D.; SAuer, J. R.; Hines, J. E. \& Pollock, K. H. 1998. Estimating species richness: the importance of heterogeneity in species detectability. Ecology 79(3):1018-1028.

BuCKLEY, L. B. \& JETZ, W. 2008. Linking global turnover of species and environments. Proceedings of the National Academy of Sciences 105:17836-17841.

Carneiro, J. S. \& Valeriano, D. M. 2003. Padrão espacial da diversidade beta da Mata Atlântica: Uma análise da distribuição da biodiversidade em banco de dados geográficos. Anais XI SBSR. INPE, Belo Horizonte, p.629-636.

Clark, D. B.; Palmer, M. W. \& Clark, D. A. 1999. Edaphic factors and the landscape-scale distributions of tropical rain forest trees. Ecology 80(8):2662-2675.

Colwell, R. K. \& Coddington, J. A. 1994. Estimating terrestrial biodiversity through extrapolation. Philosophical Transactions of the Royal Society B 345:101-118.

Cottam, G. \& Curtis, J. T. 1956. The use of distance measures in phytosociological sampling. Ecology 37(3):451-460.

CRIST, T. O. \& VEECH, J. A. 2006. Additive partitioning of rarefaction curves and species-area relationships: unifying $\alpha, \beta$ and $\gamma$ diversity with sample size and habitat area. Ecology Letters 9:923-932.

Crump, M. L. \& ScotT JR., N. J. 1994. Standard techniques for inventory and monitoring: visual encounter surveys. In: HEYER, W. R.; DONNELlY, M. A.; McDiarmid, R. W.; Hayek, L. A. C. \& Foster, M. S. eds. Measuring and monitoring biological diversity: standard methods for amphibians. Washington, Smithsonian Books, p. 84-92.

Da Costa, P. N.; Carvalho-E-Silva, S. P. de; Carvalho-E-Silva, A. M. P. T. DE \& Weber, L. N. 2008. Amphibia, Anura, Brachycephalidae, Ischnocnema holti: Distribution extension. Check List 4(3):232-233. 
DAJoz, R. 1983. Ecologia geral. 4ed. Petrópolis, Vozes. 470p.

Develey, P. 2003. Métodos com estudos com aves. In: Cullen, L.; Rudran, R. \& Valladares-Pádua, C. eds. Métodos de estudos em Biologia da Conservação \& Manejo da vida Silvestre. Curitiba, UFPR e Fundação O Boticário de Proteção à Natureza, p.153-179.

Dobrovolski, R.; Melo, A. S.; Cassemiro, F. A. S. \& Diniz-Filho, J. A. F. 2011. Climatic history and dispersal ability explain the relative importance of turnover and nestedness components of beta diversity. Global Ecology and Biogeography 21(2):1-7.

Drummond, G. M.; Martins, C. S.; Machado, A. B. M.; Sebaio, F. A. \& AnTONInI, Y. 2005. Biodiversidade em Minas Gerais: um atlas para a sua conservação. 2ed. Belo Horizonte, Fundação Biodiversitas. 222 p.

Duellman, W. E. \& Trueb, L. 1994. Biology of amphibians. McGrawHill, Baltimore. 670p.

Gardner, T. A.; Barlow, J.; Chazdon, R.; Ewers, R. M.; Harvey, C. A.; Peres, C. A. \& Sodhi, N. S. 2009. Prospects for tropical forest biodiversity in a human-modified world. Ecology Letters 12:561-582.

Gilbert, B. \& LeCHOwiCZ, M. J. 2004. Neutrality, niches and dispersal in a temperate forest understory. Proceedings of the National Academy of Sciences of the USA 101:7651-7656.

Harrison, S.; Ross, S. J. \& LaWton, J. H. 1992. Beta diversity on geographic gradients in Britain. Journal of Animal Ecology 61(1):151-158.

Herzog, S. K.; Kessler, M. \& Cahill, T. M. 2002. Estimating species richness of tropical bird communities from rapid assessment data. The Auk 119(3):749-769.

Hubbel, S. P. 2001. The unified neutral theory of biodiversity and biogeography. Princeton, Princeton University. 392p.

InTERnATIONAL Union For CONSERVATION OF NATURE - IUCN. 2013. IUCN Red List of Threatened Species. Version 2012. 1. Available at $<$ http:/ www.iucnredlist.org>. Accessed on 25 September 2013.

JiméneZ-Valverde, A.; Baselga, A.; Melic, A. \& TXAsko, N. 2010. Climate and regional beta-diversity gradients in spiders: dispersal capacity has nothing to say? Insect Conservation and Diversity 3:51-60.

Koleff, P.; Gaston, K. J. \& Lennon, J. J. 2003. Measuring beta diversity for presence-absence data. Journal of Animal Ecology 72:367-382.

Krebs, C. J. 1999. Ecological Methodology. 2ed. Menlo Park, Benjamin Cummings. 620p.

LANDE, R. 1996. Statistics and partitioning of species diversity, and similarity among multiple communities. Oikos 76:5-13.

Lawton, J. H.; Bignell, D. E.; Bolton, B.; Bloemers, G. F.; Eggleton, P.; Hammond, P. M.; Hodda, M.; Holt, R. D.; Larsen, T. B.; MaWdsley, N. A.; Stork, N. E.; Srivastava, D. S. \& Watt, A. D. 1998. Biodiversity inventories, indicator taxa and effects of habitat modification in tropical forest. Nature 391:72-76.

LEGENDRE, P. 1993. Spatial autocorrelation: Trouble or new paradigm? Ecology 74:1659-1673.

LEGENDRE, P. \& LEGENDRE, L. 2012. Numerical ecology. Oxford, Elsevier. 1006 p.

Legendre, P.; Mi, X.; Ren, H.; MA, K.; Yu, M.; Sun, I-F. \& He, F. 2009. Partitioning beta diversity in a subtropical broad-leaved forest of China. Ecology 90(3):663-674.

Magurran, A. E. 1988. Ecological diversity and its measurement. 3ed. New Jersey, Princeton University Press. 179p.

Margules, C. R. \& Pressey, R. L. 2000. Systematic conservation planning. Nature 405:243-253.

McKnight, M. W.; White, P. S.; McDonald, R. I.; Lamoreux, J. F.; Sechrest, W.; Ridgely, R. S. \& Stuart, S. N. 2007. Putting betadiversity on the map: broad-scale congruence and coincidence in the extremes. PLOS Biology 5(10):2424-2432.

MirandA, G. H. B. DE \& FAriA, D. S. DE. 2001. Ecological aspects of black-pincelled marmoset (Callithrix penicillata) in the cerradão and dense cerrado of the Brazilian Central Plateau. Brazilian Journal of Biology 61(3):397-404.

Myers, N.; Mittermeier, R. A.; Mittermeier, C. G.; Fonseca, G. A. B \& KENT, J. 2000. Biodiversity hotspots for conservation priorities. Nature 403:853-858

Nekola, J. C. \& White, P. S. 1999. The Distance Decay of Similarity in Biogeography and Ecology. Journal of Biogeography 26(4):867-878.

OliveirA-FILHO, A. T. \& FonTES, A. L. 2000. Pattern of floristic differentiation among Atlantic Forest in Southeastern Brazil and the influence of climate. Biotropica 32(4b):793-810.
Penter, C.; Pedó, E.; Fabián, M. E. \& Hartz, S. M. 2008. Inventário Rápido da Fauna de Mamíferos do Morro Santana, Porto Alegre, RS. Revista Brasileira de Biociências 6(1):117-125.

Pineda, E. \& Halffter, G. 2004. Species diversity and habitat fragmentation: frogs in a tropical montane landscape in Mexico. Biological Conservation 117:499-508.

Pinto, L. P.; Bedê, L.; Paese, A.; Fonseca, M.; Paglia, A. \& Lamas, I. 2006. Mata Atlântica Brasileira: Os Desafios para Conservação da Biodiversidade de um Hotspot Mundial. In: Rocha, C. F. D.; Bergallo, H. G.; Sluys, M. V. \& Alves, M. A. S. eds. Biologia da Conservação: Essências. São Carlos, RiMa. 582p.

QIAN, H. 2009a. Beta diversity in relation to dispersal ability for vascular plants in North America. Global Ecology and Biogeography 18:327332.

QIAN, H. 2009b. Global comparisons of beta diversity among mammals, birds, reptiles, and amphibians across spatial scales and taxonomic ranks. Journal of Systematics and Evolution 47(5):509-514.

QIAN, H. \& RickLEFs, R. E. 2012. Disentangling the effects of geographic distance and environmental dissimilarity on global patterns of species turnover. Global Ecology and Biogeography 21:341-351.

R Development Core Team. 2013. R: A language and environment for statistical computing. R Foundation for Statistical Computing. Available at: <http://www. R-project.org>. Accessed on 10 July 2013.

RickLeFs, R. E. 1987. Community Diversity: Relative Roles of Local and Regional Processes. Science 235:167-171

Rosales-Meda, M. M. 2007. Caracterización de la población del mono aullador (Alouatta palliata palliata) em el Refugio Nacional de Vida Silvestre Isla San Lucas, Costa Rica. Neotropical Primates 14(3):122127.

Scott JR., N. J. \& Woodward, B. D. 1994. Standard techniques for inventory and monitoring: surveys at breeding sites. In: HEYER, W. R.; Donnelly, M. A.; McDiarmid, R. W.; Hayek L. A. C. \& Foster M. S. eds. Measuring and monitoring biological diversity: standard methods for amphibians. Washington, Smithsonian Institution Press, p.118-125.

Silva, E. T.; Ribeiro Filho, O. P. \& Feio, R. N. 2011. Predation of native anurans by invasive bullfrogs in Southeastern Brazil: Spatial variation and effect of microhabitat use by prey. South American Journal of Herpetology 6(1):1-10.

Silveira, L. F.; Beisiegel, B. M.; Curcio, F. F.; Valdujo, P. H.; Dixo, M.; Verdade, V. K.; Mattox, G. M. T. \& Cunningham, P. T. M. 2010. What Use Do Fauna Inventories Serve? Estudos Avançados 24(68):173-207.

Soininen, J.; Lennon, J. J. \& Hillebrand, H. 2007a. A Multivariate Analysis of Beta Diversity across Organisms and Environments. Ecology 88(11):2830-2838.

Soininen, J.; McDonald, R. \& Hillebrand, H. 2007b. The distance decay of similarity in ecological communities. Ecography 30:3-12.

Steinbauer, M. J.; Dolos, K.; Reineking, B. \& Beierkuhnlein, C. 2012 Current measures for distance decay in similarity of species composition are influenced by study extent and grain size. Global Ecology and Biogeography 21:1203-1212.

Steinitz, O.; Heller, J.; Tsoar, A.; Rotem, D. \& Kadmon, R. 2006. Environment, dispersal and patterns of species similarity. Journal of Biogeography 33:1044-1054.

Stevenson, M. F. \& Rylands, A. B. 1988. The marmosets genus. In: Mittermeier, R. A.; Rylands, A. B.; Coimbra-Filho, A. F. \& Fonseca, G. A. B. eds. Ecology and Behavior of Neotropical Primates. Washington, World Wildlife Foundation, p. 131-223.

Tabarelli, M. \& Peres, C. A. 2002. Abiotic and vertebrate seed dispersal in the Brazilian Atlantic Forest: implications for forest regeneration. Biological Conservation 106:165-176.

Targino, M. \& CArvalho-E-Silva, S. P. DE. 2008. Redescrição de Ischnocnema holti (Amphibia: Anura: Brachycephalidae). Revista Brasileira de Zoologia 25(4):716-723.

Tuomisto, H.; Ruokolainen, K. \& Yli-Halla, M. 2003. Dispersal, environment, and floristic variation of western Amazonian forests. Science 299:241-244.

Tuomisto, H. 2010. A consistent terminology for quantifying species diversity? Yes, it does exist. Oecologia 164:853-860. 
Vasconcelos, T. S.; Santos, T. G.; Rossa-Feres, D. C. \& Haddad, C. F. B. 2011. Spatial and temporal distribution of tadpole assemblages (Amphibia, Anura) in a seasonal dry tropical forest of southeastern Brazil. Hydrobiologia 673:93-104.

Waters, S. S. \& Ulloa, O. 2007. Preliminary survey on the current distribution of primates in Belize. Neotropical Primates 14(2):80-82.

Werner, E. E.; Skelly, D. K.; Relyea, R. A. \& Yurewicz, K. L. 2007. Amphibian species richness across environmental gradients. Oikos 116:1697-1712.
WhitTaker, R. H. 1960. Vegetation of the Siskiyou Mountains, Oregon and California. Ecological Monographs 30:279-338.

WhitTAKER, R. H. 1972. Evolution and measurement of species diversity. Taxon 21:213-251.

WiLSON, M. V. \& ShMIDA, A. 1984. Measuring beta diversity with presenceabsence data. Journal of Ecology 72:1055-1064.

Young, B.; SedaghatKish, G. \& Roca, R. 2003. Levantamentos de fauna. In: Sayre, R.; Roca, E.; Sedaghatkish, G.; Young, B.; Keel, S.; Roca, R. \& ShePpard, S. eds. Natureza em Foco: Avaliação Ecológica Rápida. Arlington, The Nature Conservancy. 175p.

Appendix 1. Species of spermatophytes recorded in the 16 localities sampled in Minas Gerais, Brazil, and their respective frequency of occurrence (FO): R (Rare); C (Common); and F (Frequent) (AIU, Aiuruoca; BOC, Bocaina de Minas; CAM, Camanducaia; CAX, Caxambu; DEL, Delfim Moreira; EXT, Extrema; GUA, Guaxupé; MAR, Maria da Fé; MON, Monte Belo; MVE, Monte Verde; PAS, Passa Quatro; POÇ, Poços de Caldas; POU, Pouso Alegre; SGS, São Gonçalo do Sapucaí; SRJ, Santa Rita de Jacutinga; VIR, Virgínia).

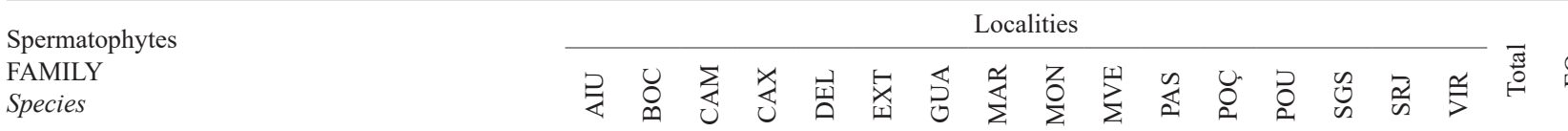

\section{ANARCADIACEAE}

Astronium fraxinifolium Schott ex Spreng.

Schinus terebinthifolius Raddi

Tapirira guianensis Aubl.

Tapirira obtusa (Benth.) J.D. Mitch.

ANNONACEAE

Annona cacans (R.E. Fr.) H. Rainer

Annona sericea Dunal

Annona sp.

Annona sylvatica A. St.-Hil.

Duguetia lanceolata A. St.-Hil.

Guatteria sp.

Guatteria australis A. St.-Hil.

Guatteria nigrescens Mart.

Xylopia brasiliensis Spreng.

Xylopia sericea A. St.-Hil.

APOCYNACEAE

Aspidosperma australe Müll. Arg.

Aspidosperma parvifolium A. DC.

Aspidosperma spruceanum Benth. ex Müll. Arg

Aspidosperma subincanum Mart. ex A. DC.

Tabernaemontana sp.

AQUIFOLIACEAE

Ilex cerasifolia Loes.

Ilex conocarpa Reissek

Ilex paraguariensis A. St.-Hil.

Ilex sapotifolia Reissek

Ilex theezans Mart. ex Reissek

ARALIACEAE

Aralia excelsa (Griseb.) J. Wen

Schefflera calva (Cham.) Frodin \& Fiaschi

Schefflera sp.

ARAUCARIACEAE

Araucaria angustifolia (Bert.) O. Kuntze

ARECACEAE

Geonoma schottiana Mart.

Syagrus romanzoffiana (Cham.) Glassman

ASTERACEAE

Baccharis serrulata (Lam.) Pers.

Eremanthus erythropappus (DC.) MacLeish

Eremanthus sp.

Piptadenia gonoacantha (Mart.) J.F. Macbr.

Piptocarpha axillaris (Less.) Baker

Piptocarpha macropoda (DC.) Baker

BIGNONIACEAE

Handroanthus catarinenses (A.H. Gentry) S. O. Grose

Jacaranda puberula Cham.

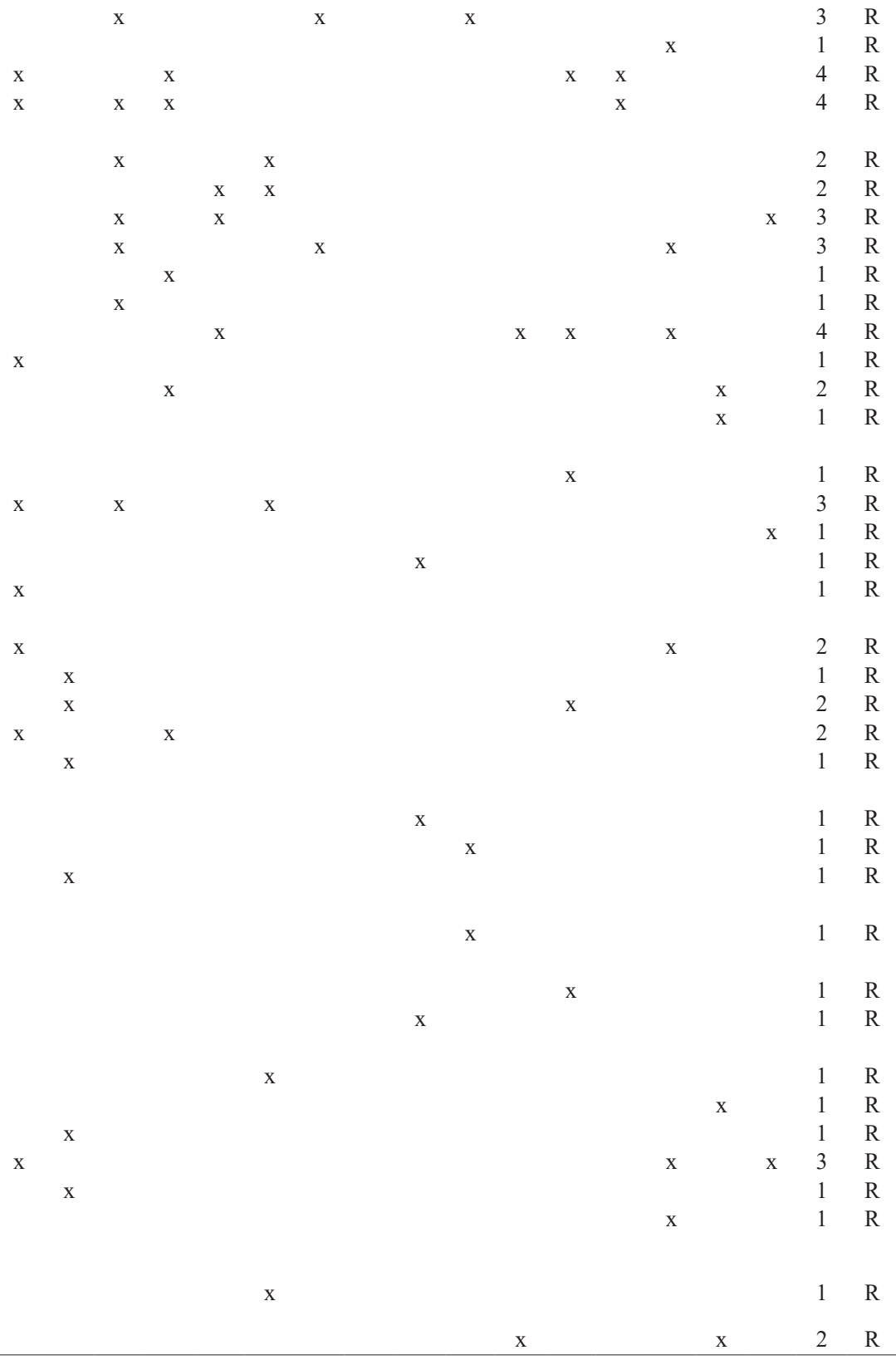


Appendix 1. Cont.

\begin{tabular}{|c|c|c|c|c|c|c|c|c|c|c|c|c|c|c|c|c|c|}
\hline \multirow{3}{*}{$\begin{array}{l}\text { Spermatophytes } \\
\text { FAMILY } \\
\text { Species }\end{array}$} & \multicolumn{16}{|c|}{ Localities } & \multirow{3}{*}{ 苟 } \\
\hline & $\sqsupseteq$ & U & $\sum$ & $x$ & $\vec{t}$ & $\sqrt[5]{x}$ & 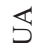 & 先 & Z & $\stackrel{1}{>}$ & 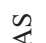 & U. & $?$ & S & $\widetilde{a}$ & $\cong$ & \\
\hline & $\varangle$ & 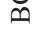 & U & ن & $\bar{a}$ & 王 & $\widetilde{\sigma}$ & $\Sigma$ & $\Sigma$ & $\Sigma$ & $\approx$ & 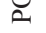 & ح & $\varpi$ & $\bar{n}$ & $>$ & \\
\hline
\end{tabular}

\section{BORAGINACEAE}

Cordia sellowiana Cham.

Cordia sp.

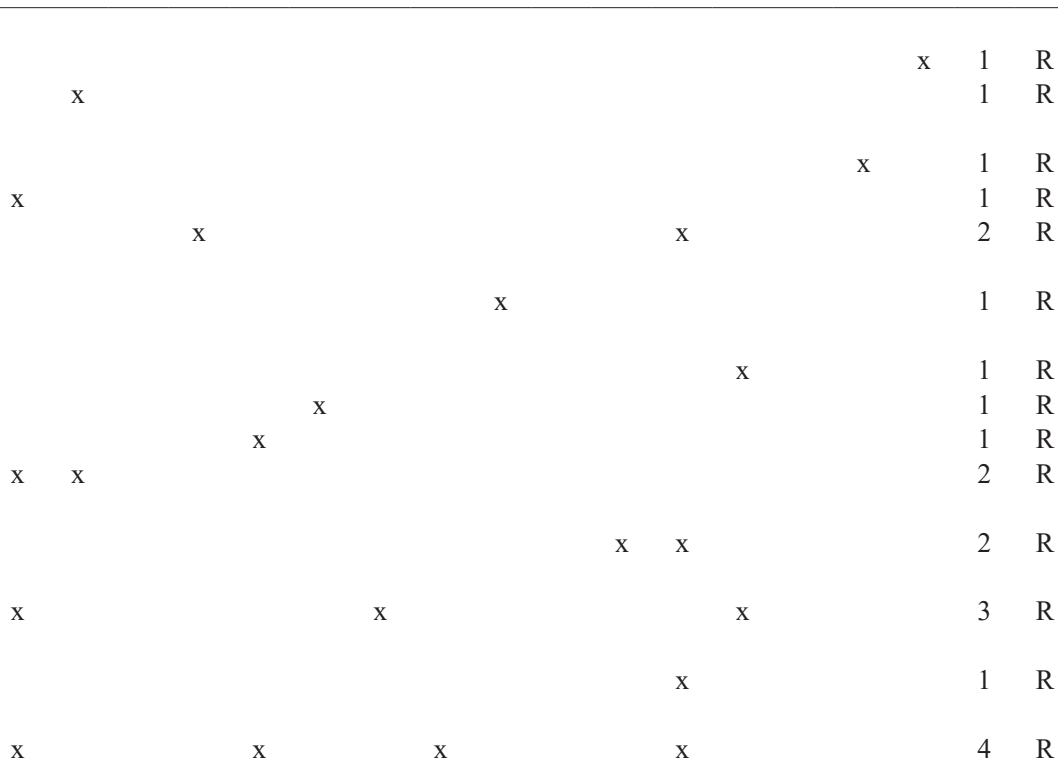

Protium heptaphyllum (Aubl.) Marchand

Protium spruceanum (Benth.) Engl.

Protium widgrenii Engl.

CARICACEAE

Jacaratia spinosa (Aubl.) A. DC.

CELASTRACEAE

Maytenus ilicifolia Mart. ex Reissek

Maytenus robusta Reissek

Maytenus salicifolia Reissek

Maytenus sp.

CLETHRACEAE

Clethra scabra Pers.

CONNARACEAE

Connarus regnellii $\mathrm{G}$. Schellenb.

DICKSONIACEAE

Dicksonia sellowiana Sodiro

ELAEOCARPACEAE

Sloanea hirsuta (Schott) Planch. ex Benth.

Alchornea castaneifolia (Humb. \& Bonpl. ex

Willd.) A. Juss.

Alchornea cf. triplinervia

Alchornea glandulosa Poepp.

Alchornea sidifolia Müll. Arg.

Alchornea triplinervia (Spreng.) M. Arg.

Aparisthmium cordatum (A.Juss.) Baill

Croton floribundus Spreng.

Croton organensis Baill.

Maprounea guianensis Aubl.

Pera glabrata (Schott) Poepp. ex Baill.

Sapium glandulosum (L.) Morong

Sebastiania commersoniana (Baill.) L.B. Sm. \&

Downs

Sebastiania serrata (Baill. ex Müll. Arg.) Müll. Arg.

FABACEAE

Anadenanthera sp.

Apuleia leiocarpa (Vogel) J.F. Macbr.

Bauhinia forficata Link

Bauhinia rufa (Bong.) Steud.

Bauhinia sp.

Copaifera langsdorffii Desf.

Copaifera sp.

Dalbergia frutescens (Vell.) Britton

Dalbergia villosa (Benth.) Benth.

Diplotropis ferruginea Benth.

Holocalyx balansae Micheli

Hymenaea courbaril L.

Inga vera Willd.

Machaerium brasiliense Vogel

Machaerium hirtum (Vell.) Stellfeld

Machaerium villosum Vogel

Myroxylon peruiferum L. f.

Ormosia fastigiata Tul.

Platycyamus regnellii Benth.

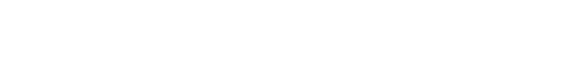

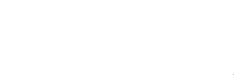

X 1 R

$\begin{array}{llll}\mathrm{X} & \mathrm{x} & 2 & \mathrm{R}\end{array}$

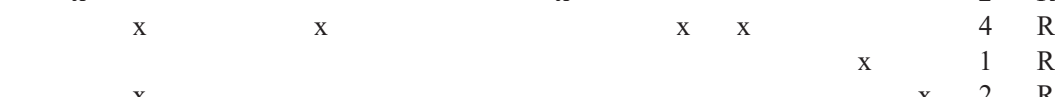

$\begin{array}{llllll}x & & x & 2 & R \\ & x & & 1 & R\end{array}$

$\mathrm{x} \quad \mathrm{x}-\mathrm{x} \quad \mathrm{x}$

$\mathrm{x}$

$\begin{array}{lll}5 & \mathrm{C} \\ \mathrm{X} & 2 & \mathrm{R}\end{array}$

$\mathrm{x}$

$\mathrm{X}$

X $\quad \mathrm{X}-\mathrm{X}$
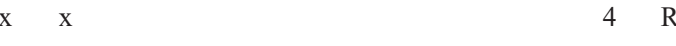

Podocarpus sellowii Klotzsch ex Endl.

Pseudopiptadenia sp.

Pterocarpus rohri Vahl

Senegalia polyphylla (DC.) Britton

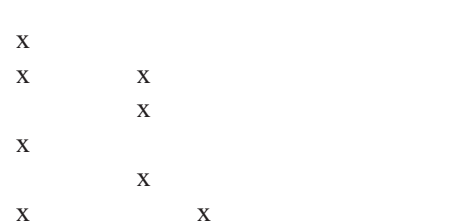


Appendix 1. Cont.

Spermatophytes

FAMILY

Species

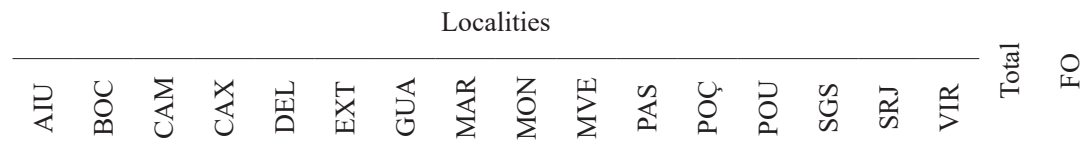

Senna macranthera (DC. ex Collad.) H.S. Irwin \&

Barneby

Stryphnodendron polyphyllum Mart.

Swartzia flaemingii Raddi

Swartzia myrtifolia $\mathrm{Sm}$.

Tachigali rugosa (Mart. ex Benth.) Zarucchi \&

Pipoly

Vernonanthura divaricata (Spreng.) H. Rob.

Vernonanthura sp.

HUMIRIACEAE

Vantanea compacta (Schnizl.) Cuatrec.

HYPERICACEAE

Vismia guianensis (Aubl.) Pers.

$\mathrm{x}$

Vismia magnoliifolia Schltdl. \& Cham.

Vismia sp.

Vitex megapotamica (Spreng.) Moldenke

LACISTEMATACEAE

Lacistema hasslerianum Chodat

LAMIACEAE

Vitex polygama Cham.

LAURACEAE

Aniba firmula (Nees \& Mart. ex Nees) Mez

Aniba sp.

Cinnamomum glaziovii (Mez) Kosterm.

Cinnamomum triplinerve (Ruiz \& Pav.) Kosterm.

Cryptocarya aschersoniana Mez

Endlicheria paniculata (Spreng.) J.F. Macbr.

Endlicheria verticillata $\mathrm{Mez}$

Lauraceae sp. 1

Nectandra oppositifolia Nees \& Mart.

Ocotea aciphylla (Nees \& Mart.) Mez

Ocotea brachybotrya (Meisn.) Mez

Ocotea corymbosa (Meisn.) Mez

Ocotea diospyrifolia (Meisn.) Mez

Ocotea divaricata (Nees) Mez

Ocotea minarum (Nees \& Mart.) Mez

Ocotea odorifera Rohwer

Ocotea sp.

Persea rufotomentosa Nees \& C. Mart.

MALVACEAE

Ceiba speciosa (A. St.-Hil.) Ravenna

Luehea candicans Mart.

Luehea grandiflora Mart.

MELASTOMATACEAE

Leandra scabra DC.

Leandra sp.

Miconia castaneifolia Naudin

Miconia cf. petropolitana Cogn.

Miconia chartacea Triana

Miconia cinerascens Miq.

Miconia cinnamomifolia (DC.) Naudin

Miconia latecrenata (DC.) Naudin

Miconia pusilliflora (DC.) Naudin

Miconia sellowiana Naudin

Miconia sp

Miconia tristes Spring

Miconia urophylla DC

Miconia willdenowii Klotzsch ex Naudin

Tibouchina estrellensis (Raddi) Cogn.

Tibouchina fissinervia Cogn.

Tibouchina fothergillae (DC.) Cogn.

Tibouchina granulosa (Desr.) Cogn.
$\mathrm{X}$

$\begin{array}{lll} & 1 & \mathrm{R} \\ \mathrm{x} & 1 & \mathrm{R}\end{array}$
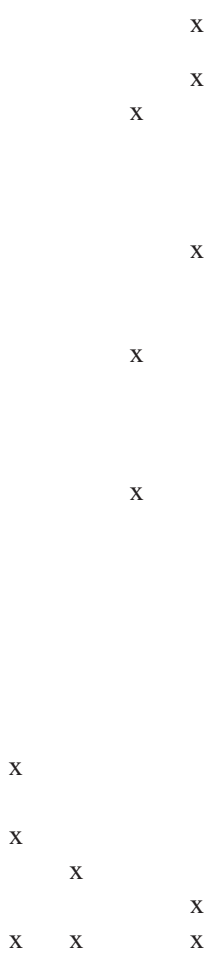

$\mathrm{X}$
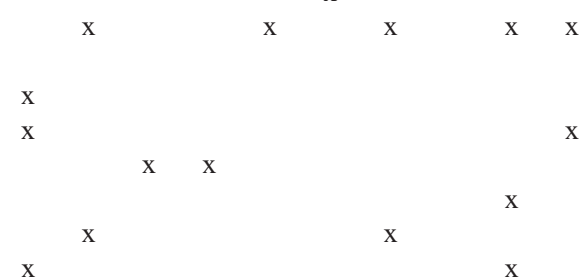

\section{$\mathrm{X}$}

X

X $3 \mathrm{R}$
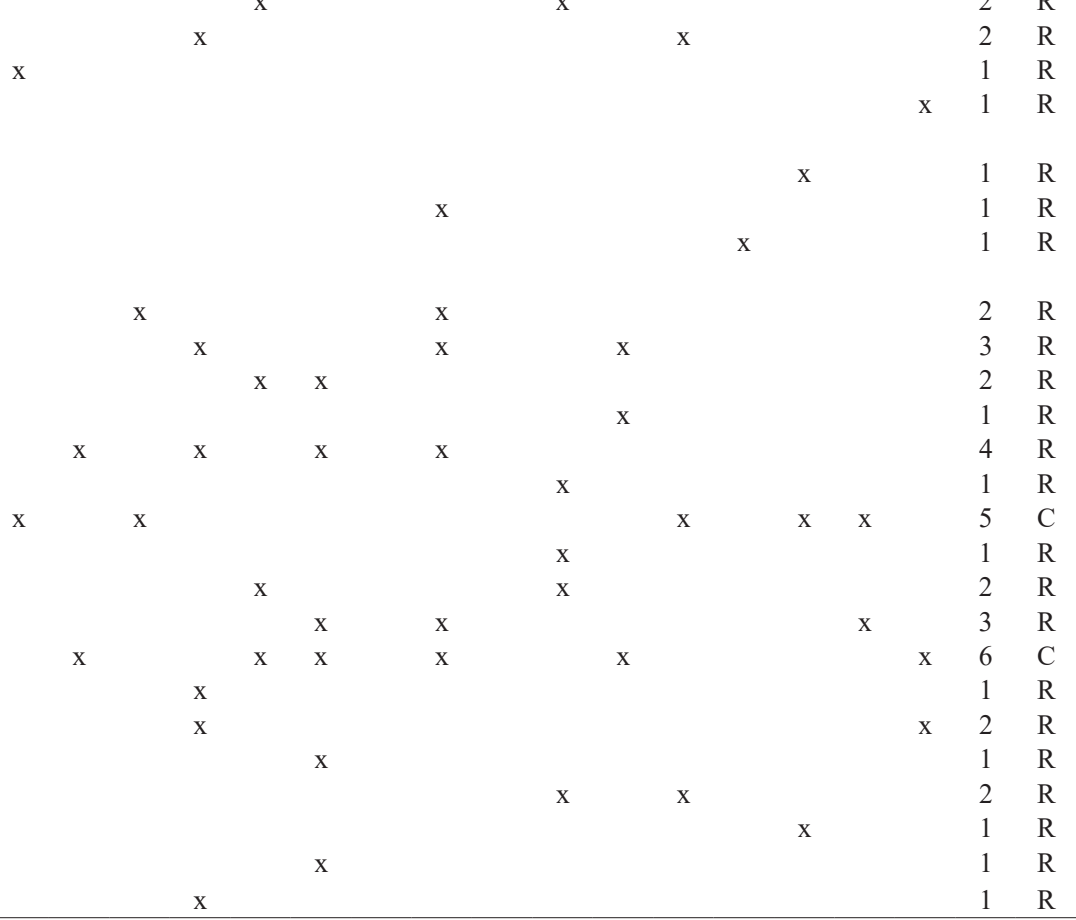
Appendix 1. Cont.

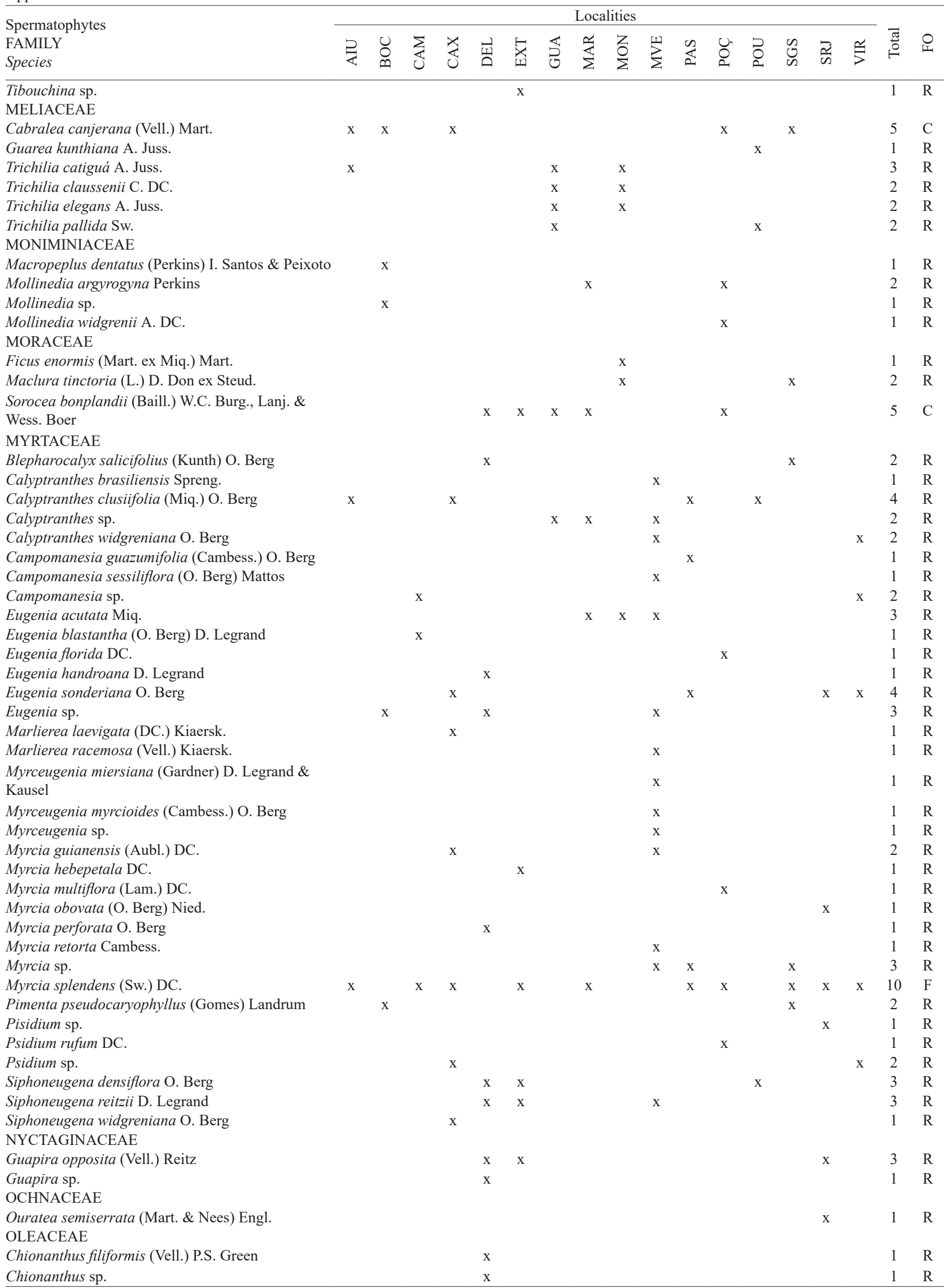


Appendix 1. Cont.

\begin{tabular}{|c|c|c|c|c|c|c|c|c|c|c|c|c|c|c|c|c|c|}
\hline \multirow{2}{*}{$\begin{array}{l}\text { Spermatophytes } \\
\text { FAMILY } \\
\text { Species }\end{array}$} & \multicolumn{16}{|c|}{ Localities } & \multirow[b]{2}{*}{ 苞 } \\
\hline & き & ৩ & $\sum_{\circlearrowright}$ & $\underset{J}{J}$ & 可 & $\underset{-1}{\sqrt[x]{x}}$ & $\underset{Ð}{Ð}$ & $\stackrel{\sim}{\longleftarrow}$ & Zু & $\sum^{1}$ & $\stackrel{\infty}{\Delta}$ & ○ & 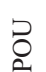 & D & $\overrightarrow{\widetilde{\sim}}$ & $\stackrel{\sim}{>}$ & \\
\hline
\end{tabular}

\section{OPILIACEAE}

Agonandra excelsa Griseb.

PENTAPHYLACACEAE

Ternstroemia brasiliensis Cambess.

PHYLLANTHACEAE

Hyeronima alchornioides Allemão

PHYTOLACCACEAE

Gallesia integrifólia (Spreng.) Harms

PRIMULACEAE

Myrsine coriacea (Sw.) R. Br. ex Roem. \& Schult

Myrsine lineata (Mez) Imkhan.

Myrsine sp.

Myrsine umbellata Mart.

PROTEACEAE

Euplassa rufa (Loes.) Sleumer

Roupala meisneri Sleumer

Roupala montana Aubl.

RHAMNACEAE

Rhamnidium elaeocarpum Reissek

ROSACEAE

Prunus myrtifolia (L.) Urb.

RUBIACEAE

Alseis sp.

Amaioua guianensis Aubl.

Chomelia sericea Müll. Arg.

Cordiera concolor (Cham.) Kuntze

Cordiera sp.

Coussarea contracta (Walp.) Müll. Arg.

Coussarea sp.

Coutarea hexandra (Jacq.) K. Schum.

Ixora brevifolia Benth.

Ixora $\mathrm{sp.}$

Psychotria myriantha Müll. Arg.

Psychotria sp.

Psychotria vellosiana Benth.

Rudgea jasminoides (Cham.) Müll. Arg.

Rudgea $\mathrm{sp}$.

RUTACEAE

Metrodorea nigra A. St.-Hil.

Metrodorea stipularis Mart.

Zanthoxylum fagara (L.) Sarg.

SABIACEAE

Meliosma sinuata Urb.

SALICACEAE

Casearia decandra Jacq.

Casearia lasiophylla Eichler

Casearia obliqua Spreng.

Casearia sylvestris Sw.

Prockia crucis P. Browne ex L.

SAPINDACEAE

Cupania paniculata Cambess.

Cupania vernalis Cambess.

Cupania zanthoxyloides Cambess.

Matayba cf. robusta Radlk.

Matayba guianensis Aubl.

Matayba juglandifolia Radlk.

Toulicia subsquamulata Radlk.

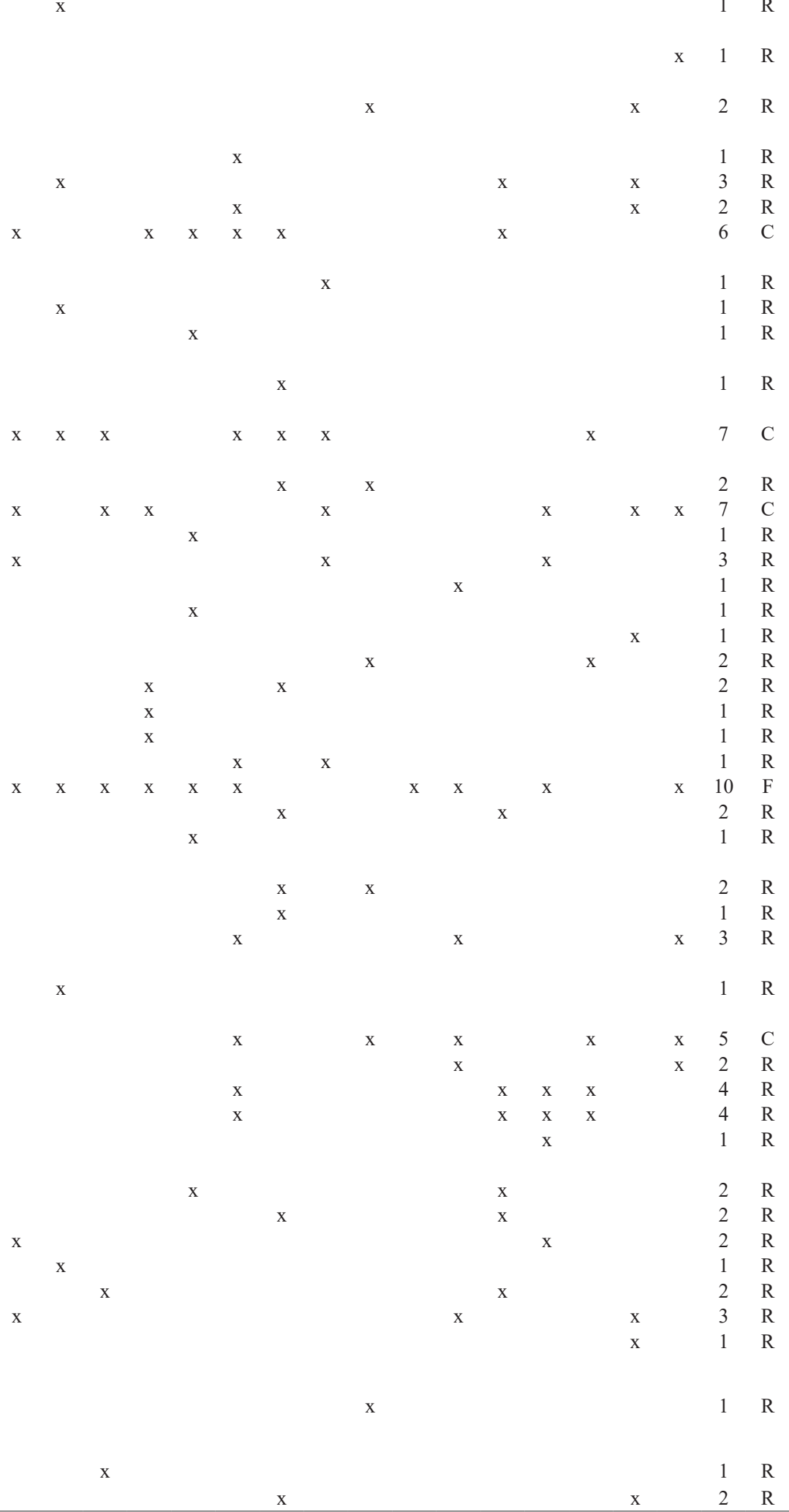

Chrysophyllum gonocarpum (Mart. \& Eichler ex

Miq.) Engl.

SIPARUNACEAE

Siparuna brasiliensis (Spreng.) A. DC.

Siparuna guianensis Aubl. 
Appendix 1. Cont.

\begin{tabular}{|c|c|c|c|c|c|c|c|c|c|c|c|c|c|c|c|c|c|c|}
\hline \multirow{2}{*}{$\begin{array}{l}\text { Spermatophytes } \\
\text { FAMILY } \\
\text { Species }\end{array}$} & \multicolumn{16}{|c|}{ Localities } & \multirow[b]{2}{*}{ 营 } & \multirow[b]{2}{*}{ O } \\
\hline & 五 & ঠৃ & $\sum_{\circlearrowright}^{\Sigma}$ & 赁 & 武 & 武 & 忌 & $\stackrel{\nwarrow}{z}$ & $\stackrel{\text { Z }}{\varrho}$ & $\sum^{1}$ & $\sum_{\underline{\Omega}}^{\infty}$ & ஓ & २ & D & $\overrightarrow{\widetilde{L}}$ & $\cong$ & & \\
\hline \multicolumn{19}{|l|}{ SOLANACEAE } \\
\hline Aureliana velutina Sendtn. & & & & & & & & & & & & $\mathrm{x}$ & & & & & 1 & $\mathrm{R}$ \\
\hline Solanum pseudoquina A. St.-Hil. & & & & & & $\mathrm{x}$ & & & & & & & & & & $\mathrm{x}$ & 2 & $\mathrm{R}$ \\
\hline Solanum sp. & & & & & & $\mathrm{x}$ & & & & & & & & & & $\mathrm{x}$ & 2 & $\mathrm{R}$ \\
\hline \multicolumn{19}{|l|}{ STYRACACEAE } \\
\hline Styrax latifolius Pohl & & & & & & & & & & & & & & & & $\mathrm{x}$ & 1 & $\mathrm{R}$ \\
\hline \multicolumn{19}{|l|}{ SYMPLOCACEAE } \\
\hline Symplocos celastrina Mart. ex Miq. & & $\mathrm{x}$ & $\mathrm{x}$ & & & & & & & & & & & & & & 2 & $\mathrm{R}$ \\
\hline Symplocos insignis Brade,A. & & & & & & & & & & $\mathrm{x}$ & & & & & & & 1 & $\mathrm{R}$ \\
\hline Symplocos pubescens Klotzsch ex Benth. & & & $\mathrm{x}$ & & & & & & & & & & & & & & 1 & $\mathrm{R}$ \\
\hline THEACEAE & & & & & & & & & & & & & & & & & & \\
\hline $\begin{array}{l}\text { Laplacea fruticosa (Schrad.) Kobuski } \\
\text { THYMELAEACEAE }\end{array}$ & & $\mathrm{x}$ & & & & & & & & & & & & & & & 1 & $\mathrm{R}$ \\
\hline Daphnopsis fasciculata (Meisn.) Nevling & & & & & & & & & & & & $\mathrm{x}$ & & & & & 1 & $\mathrm{R}$ \\
\hline Daphnopsis utilis Warm. & & & & & & & & & & & & & & & & $\mathrm{x}$ & 1 & $\mathrm{R}$ \\
\hline \multicolumn{19}{|l|}{ URTICACEAE } \\
\hline Cecropia glaziovii Snethl. & & & & & & & & & & & & & & $\mathrm{x}$ & & & 1 & $\mathrm{R}$ \\
\hline Cecropia sp. & & & & & & & & & & & & & $\mathrm{x}$ & & & & 1 & $\mathrm{R}$ \\
\hline Urera bacifera (L.) Gaudich. & & & & & & & $\mathrm{x}$ & & $\mathrm{x}$ & & & & & & & & 2 & $\mathrm{R}$ \\
\hline \multicolumn{19}{|l|}{ VOCHYSIACEAE } \\
\hline Qualea cryptantha (Spreng.) Warm. & & & & & & & & & & & & $\mathrm{x}$ & & & & & 1 & $\mathrm{R}$ \\
\hline Qualea dichotoma (Mart.) Warm. & & & & & & & & & & & & & & & & $\mathrm{x}$ & 1 & $\mathrm{R}$ \\
\hline Vochysia grandis Mart. & & & & & & & & $\mathrm{x}$ & & & & & & & & & 1 & $\mathrm{R}$ \\
\hline $\begin{array}{l}\text { Vochysia magnifica Warm. } \\
\text { WINTERACEAE }\end{array}$ & $\mathrm{x}$ & & & & & $\mathrm{x}$ & & & & & & & $\mathrm{x}$ & & & $\mathrm{x}$ & 4 & $\mathrm{R}$ \\
\hline Drimys brasiliensis Miers & & $\mathrm{x}$ & & & & & & & & $\mathrm{x}$ & & & & & & & 2 & $\mathrm{R}$ \\
\hline Total & 38 & 29 & 34 & 34 & 35 & 39 & 27 & 22 & 23 & 31 & 26 & 37 & 28 & 27 & 31 & 36 & & \\
\hline
\end{tabular}

Appendix 2. Species of amphibians recorded in the 16 localities sampled in Minas Gerais, Brazil, and their respective frequency of occurrence (FO): R (Rare); C (Common); and F (Frequent) (AIU, Aiuruoca; BOC, Bocaina de Minas; CAM, Camanducaia; CAX, Caxambu; DEL, Delfim Moreira; EXT, Extrema; GUA, Guaxupé; MAR, Maria da Fé; MON, Monte Belo; MVE, Monte Verde; PAS, Passa Quatro; POÇ, Poços de Caldas; POU, Pouso Alegre; SGS, São Gonçalo do Sapucaí; SRJ, Santa Rita de Jacutinga; VIR, Virgínia).

\begin{tabular}{|c|c|c|c|c|c|c|c|c|c|c|c|c|c|c|c|c|c|c|}
\hline \multirow{2}{*}{$\begin{array}{l}\text { Amphibians } \\
\text { FAMILY } \\
\text { Species }\end{array}$} & \multicolumn{16}{|c|}{ Localities } & \multirow[b]{2}{*}{$\stackrel{\pi}{0}$} & \multirow[b]{2}{*}{$\mathrm{FO}$} \\
\hline & 巳 & ְৃ & $\sum_{\circlearrowright}$ & $\underset{3}{x}$ & $\stackrel{+1}{a}$ & $\underset{⿱ ㇒ 士}{x}$ & $\underset{Ð}{Ð}$ & $\sum_{\Sigma}^{\sim}$ & Z & $\sum_{\Sigma}^{\infty}$ & $\sum_{a}^{\infty}$ & 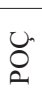 & ? & $\underset{\mathscr{S}}{\mathscr{S}}$ & $\vec{\sim}$ & $\stackrel{\sim}{\not}$ & & \\
\hline \multicolumn{19}{|l|}{ BRACHYCEPHALIDAE } \\
\hline Ischnocnema guentheri (Steindachner, 1864) & & $\mathrm{x}$ & & & $\mathrm{x}$ & $\mathrm{x}$ & & $\mathrm{X}$ & $\mathrm{x}$ & $\mathrm{x}$ & & & & $\mathrm{x}$ & & & 7 & $\mathrm{C}$ \\
\hline Ischnocnema holti (Cochran, 1948) & & & & & & $\mathrm{x}$ & & & & & & & & & & & 1 & $\mathrm{R}$ \\
\hline \multicolumn{19}{|l|}{ BUFONIDAE } \\
\hline Rhinella icterica (Spix, 1824) & & $\mathrm{x}$ & & $\mathrm{x}$ & $\mathrm{x}$ & $\mathrm{x}$ & & $\mathrm{x}$ & & $\mathrm{x}$ & $\mathrm{x}$ & $\mathrm{x}$ & $\mathrm{x}$ & & $\mathrm{x}$ & $\mathrm{x}$ & 11 & $\mathrm{~F}$ \\
\hline Rhinella ornata (Spix, 1824) & & & & & & & & & $\mathrm{x}$ & & & & & $\mathrm{x}$ & & & 2 & $\mathrm{R}$ \\
\hline Rhinella rubescens (Lutz, 1925) & $\mathrm{x}$ & & & & & & & & & & & $\mathrm{x}$ & & & & & 2 & $\mathrm{R}$ \\
\hline $\begin{array}{l}\text { Rhinella schneideri (Werner, 1894) } \\
\text { CRAUGASTORIDAE }\end{array}$ & & & & & & & & & $\mathrm{x}$ & & & & & & & & 1 & $\mathrm{R}$ \\
\hline $\begin{array}{l}\text { Haddadus binotatus (Spix, 1824) } \\
\text { CYCLORAMPHIDAE }\end{array}$ & & & & & & & & & $\mathrm{x}$ & & & & & & $\mathrm{x}$ & & 2 & $\mathrm{R}$ \\
\hline $\begin{array}{l}\text { Odontophrynus americanus (Duméril \& Bibron, } \\
\text { 1841) }\end{array}$ & & & & & $\mathrm{x}$ & & & & & & & & & & & & 1 & $\mathrm{R}$ \\
\hline Proceratophrys boiei (Wied-Neuwied, 1824) & & & & & $\mathrm{x}$ & $\mathrm{x}$ & & $\mathrm{x}$ & & & & & & & & & 3 & $\mathrm{R}$ \\
\hline $\begin{array}{l}\text { Proceratophrys appendiculata (Günther, 1873) } \\
\text { HYLIDAE }\end{array}$ & & $\mathrm{x}$ & & & & & & & & & & & & & & & 1 & $\mathrm{R}$ \\
\hline Aplastodiscus arildae (Cruz \& Peixoto, 1985) & & $\mathrm{x}$ & & & & & & & & & & & & & & & 1 & $\mathrm{R}$ \\
\hline $\begin{array}{l}\text { Aplastodiscus leucopygius (Cruz \& Peixoto, } 1985 \\
\text { “1984”) }\end{array}$ & & & & $\mathrm{x}$ & $\mathrm{x}$ & $\mathrm{x}$ & & & & & & & & & & & 3 & $\mathrm{R}$ \\
\hline Aplastodiscus perviridis A. Lutz in B. Lutz, 1950 & & & & & & & & & & $\mathrm{x}$ & & $\mathrm{x}$ & & & & & 2 & $\mathrm{R}$ \\
\hline Bokermannohyla circumdata (Cope, 1871) & & $\mathrm{x}$ & $\mathrm{x}$ & & & & & & & $\mathrm{x}$ & & & & & & & 3 & $\mathrm{R}$ \\
\hline $\begin{array}{l}\text { Bokermannohyla luctuosa (Pombal \& Haddad, } \\
\text { 1993) }\end{array}$ & $\mathrm{x}$ & & & & & & $\mathrm{x}$ & $\mathrm{x}$ & & & $\mathrm{x}$ & & & & & & 4 & $\mathrm{R}$ \\
\hline
\end{tabular}


Appendix 2. Cont.

Amphibians

FAMILY

Localities

Species

己

Bokermannohyla vulcaniae De Vasconcelos \&

Giaretta, 2005

Dendropsophus elegans (Wied-Neuwied, 1824)

Dendropsophus microps (Peters, 1872)

Dendropsophus minutus (Peters, 1872)

Dendropsophus rubicundulus (Reinhardt and

Lütken, 1862)

Dendropsophus sanborni (Schmidt, 1944)

Hypsiboas albopunctatus (Spix, 1824)

Hypsiboas faber (Wied-Neuwied, 1821)

Hypsiboas semilineatus (Spix, 1824)

Hypsiboas lundii (Burmeister, 1856)

Hypsiboas pardalis (Spix, 1824)

Hypsiboas polytaenius (Cope, 1870"1869")

Hypsiboas prasinus (Burmeister, 1856)

Phasmahyla cochranae (Bokermann, 1966)

Scinax crospedospilus (A. Lutz, 1925)

Scinax flavoguttatus (A. Lutz and B. Lutz, 1939)

Scinax fuscovarius (Lutz, 1925)

Scinax hayii (Barbour, 1909)

Scinax longilineus (B. Lutz, 1968)

Scinax ranki (Andrade \& Cardoso, 1987)

LEIUPERIDAE

Eupemphix nattereri Steindachner, 1863

Physalaemus centralis Bokermann, 1962

Physalaemus cuvieri Fitzinger, 1826

Physalaemus olfersii (Lichtenstein and Martens,

1856)

LEPTODACTYLIDAE

Leptodactylus fuscus (Schneider, 1799)

Leptodactylus labyrinthicus (Spix, 1824)

Leptodactylus latrans (Steffen, 1815)

Leptodactylus mystacinus (Burmeister, 1861)

RANIDAE

Lithobates catesbeianus (Shaw, 1802)**

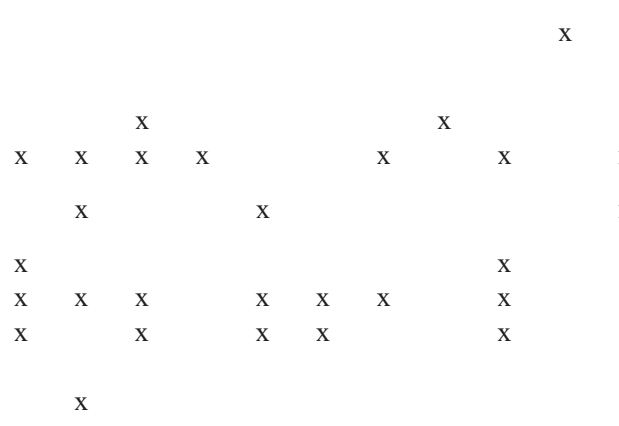

$\begin{array}{cccc} & & 1 & \mathrm{R} \\ \mathrm{x} & \mathrm{x} & 2 & \mathrm{R} \\ & & 2 & \mathrm{R} \\ & \mathrm{x} & 8 & \mathrm{C} \\ & \mathrm{x} & 4 & \mathrm{R} \\ & & & \\ \mathrm{x} & & 2 & \mathrm{R} \\ \mathrm{x} & & 8 & \mathrm{C} \\ \mathrm{x} & & 7 & \mathrm{C} \\ \mathrm{x} & & 1 & \mathrm{R} \\ & & 1 & \mathrm{R} \\ & & 1 & \mathrm{R} \\ \mathrm{x} & & 10 & \mathrm{~F} \\ & & 1 & \mathrm{R} \\ & & 1 & \mathrm{R} \\ \mathrm{x} & & 2 & \mathrm{R} \\ & & 1 & \mathrm{R} \\ & \mathrm{x} & 5 & \mathrm{C} \\ & & 1 & \mathrm{R} \\ & & 3 & \mathrm{R} \\ & & 1 & \mathrm{R} \\ & & & \\ & & 1 & \mathrm{R} \\ & \mathrm{x} & 1 & \mathrm{R} \\ & \mathrm{x} & 7 & \mathrm{C} \\ & & 1 & \mathrm{R} \\ & & & \\ & & & \\ & & & \\ & & \end{array}$

Appendix 3. Species of birds recorded in the 16 localities sampled in Minas Gerais, Brazil, and their respective frequency of occurrence (FO): R (Rare); C (Common); and F (Frequent) (AIU, Aiuruoca; BOC, Bocaina de Minas; CAM, Camanducaia; CAX, Caxambu; DEL, Delfim Moreira; EXT, Extrema; GUA, Guaxupé; MAR, Maria da Fé; MON, Monte Belo; MVE, Monte Verde; PAS, Passa Quatro; POÇ, Poços de Caldas; POU, Pouso Alegre; SGS, São Gonçalo do Sapucaí; SRJ, Santa Rita de Jacutinga; VIR, Virgínia).

Birds

FAMILY

Species

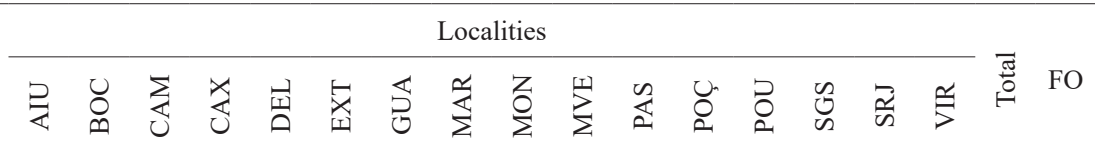

ACCIPITRIDAE

Buteo nitidus (Latham, 1790)*

Heterospizias meridionalis (Latham, 1790)*

Rupornis magnirostris (Gmelin, 1788)*

ALCEDINIDAE

Chloroceryle americana (Gmelin, 1788)

Megaceryle torquata (Linnaeus, 1766)*

x $\quad \mathrm{x} \quad \mathrm{X} \quad \mathrm{x}$

$\mathrm{x} \quad \mathrm{x}$

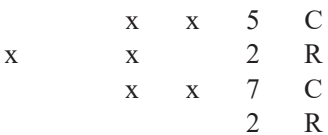

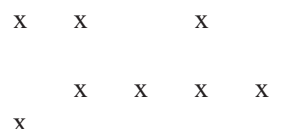

$\mathrm{x}$

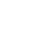

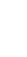

ARDEIDAE

Bubulcus íbis (Linnaeus, 1758)*

BUCCONIDAE

Malacoptila striata (Spix, 1824)

CARDINALIDAE

Habia rubica (Vieillot, 1817)

Piranga flava (Vieillot, 1822)*

Saltator fuliginosus (Daudin, 1800)*

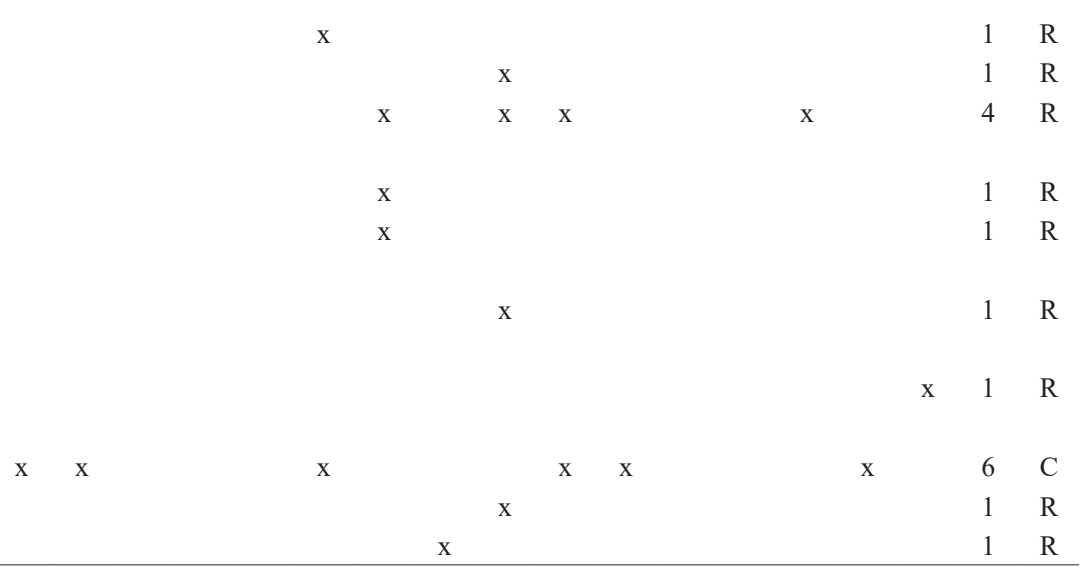


Appendix 3. Cont.

\begin{tabular}{|c|c|c|c|c|c|c|c|c|c|c|c|c|c|c|c|c|c|c|}
\hline \multirow{2}{*}{$\begin{array}{l}\text { Birds } \\
\text { FAMILY } \\
\text { Species }\end{array}$} & \multicolumn{16}{|c|}{ Localities } & \multirow[b]{2}{*}{ } & \multirow[b]{2}{*}{$\mathrm{FC}$} \\
\hline & 乬 & ঠூ & $\sum_{\circlearrowright}$ & $\underset{ن}{x}$ & $\stackrel{\overrightarrow{1}}{0}$ & 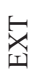 & 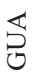 & $\underset{\Sigma}{\Sigma}$ & 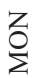 & $\sum_{\Sigma}^{1}$ & $\sum_{2}^{\infty}$ & Ð & ?ְ & 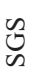 & $\overrightarrow{\widetilde{\alpha}}$ & $\stackrel{\sim}{\Rightarrow}$ & & \\
\hline \multicolumn{18}{|l|}{ CARIAMIDAE } & \\
\hline Cariama cristata (Linnaeus, 1766)* & & & $\mathrm{x}$ & & & & $\mathrm{x}$ & & & & & $\mathrm{x}$ & & $\mathrm{x}$ & & & 4 & $\mathrm{R}$ \\
\hline \multicolumn{18}{|l|}{ COEREBIDAE } & \\
\hline Coereba flaveola (Linnaeus, 1758) & $\mathrm{x}$ & & & & & & $\mathrm{x}$ & & & & & & $\mathrm{x}$ & & & & 3 & $\mathrm{R}$ \\
\hline \multicolumn{18}{|l|}{ COLUMBIDAE } & \\
\hline Columbina squammata (Lesson, 1831)* & & & & & & & & & $\mathrm{x}$ & & & & & & & & 1 & $\mathrm{R}$ \\
\hline Columbina talpacoti (Temminck, 1809)* & & & & & & & $\mathrm{X}$ & & $\mathrm{X}$ & & $\mathrm{x}$ & & & $\mathrm{X}$ & $\mathrm{x}$ & & 5 & $\mathrm{C}$ \\
\hline Leptotila rufaxilla (Richard \& Bernard, 1792) & & & & & & & & & & & & & $\mathrm{x}$ & & & & 1 & $\mathrm{R}$ \\
\hline Patagioenas plumbea Vieillot, 1818 & & & & & $\mathrm{x}$ & $\mathrm{x}$ & & & & $\mathrm{x}$ & & & & & & & 3 & $\mathrm{R}$ \\
\hline \multicolumn{18}{|l|}{ CONOPOPHAGIDAE } & \\
\hline Conopophaga lineata (Wied, 1831) & $\mathrm{x}$ & & & $\mathrm{x}$ & & $\mathrm{x}$ & & $\mathrm{x}$ & & & & $\mathrm{x}$ & $\mathrm{x}$ & $\mathrm{x}$ & & $\mathrm{x}$ & 8 & $\mathrm{C}$ \\
\hline \multicolumn{18}{|l|}{ CORVIDAE } & \\
\hline Cyanocorax cristatellus Temminck, 1823* & & & & & & & & & $\mathrm{x}$ & & & & & & & & 1 & $\mathrm{R}$ \\
\hline \multicolumn{18}{|l|}{ COTINGIDAE } & \\
\hline Pachyramphus validus (Lichtenstein, 1823)* & & & & & & & & & & & & $\mathrm{x}$ & & & & & 1 & $\mathrm{R}$ \\
\hline Schiffornis virescens (Lafresnaye, 1838) & & & & & & & & & & & & $\mathrm{x}$ & & & & & 1 & $\mathrm{R}$ \\
\hline \multicolumn{18}{|l|}{ CRACIDAE } & \\
\hline Penelope obscura Temminck, 1815* & & & & & & $\mathrm{x}$ & & & & & $\mathrm{x}$ & & & & & & 2 & $\mathrm{R}$ \\
\hline \multicolumn{18}{|l|}{ CUCULIDAE } & \\
\hline Crotophaga ani Linnaeus, 1758* & & & & & & & & & $\mathrm{x}$ & & & & & & & & 1 & $\mathrm{R}$ \\
\hline Guira guira (Gmelin, 1788)* & & & & & & & & & $\mathrm{X}$ & & & & & & $\mathrm{x}$ & & 2 & $\mathrm{R}$ \\
\hline Piaya cayana (Linnaeus, 1766)* & & & & & & & $\mathrm{X}$ & $\mathrm{x}$ & & & $\mathrm{x}$ & $\mathrm{X}$ & & $\mathrm{X}$ & & & 5 & $\mathrm{C}$ \\
\hline
\end{tabular}

\section{DENDROCOLAPTIDAE}

Lepidocolaptes angustirostris (Vieillot, 1818)

Sittasomus griseicapillus (Vieillot, 1818)

Xiphorhynchus fuscus (Vieillot, 1818)

EMBERIZIDAE

Haplospiza unicolor Cabanis, 1851*

Sicalis flaveola (Linnaeus, 1766)*

Sporophila caerulescens (Vieillot, 1823)*

Sporophila lineola (Linnaeus, 1758)

Volatinia jacarina (Linnaeus, 1766)*

Zonotrichia capensis (Müller, 1776)*

FALCONIDAE

Caracara plancus (Miller, 1777)*

FORMICARIIDAE

Chamaeza ruficauda (Cabanis \& Heine, 1859)*

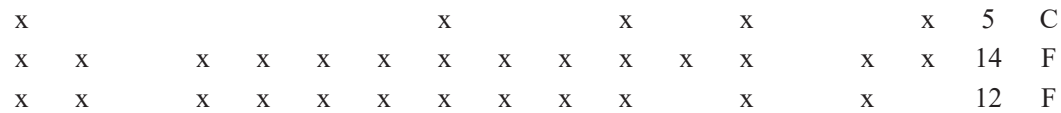

FURNARIIDAE

Automolus leucophthalmus (Wied, 1821)

Cranioleuca pallida (Wied, 1831)*

Furnarius rufus (Gmelin, 1788)*

Heliobletus contaminatus Berlepsch, 1885*

Lochmias nematura (Lichtenstein, 1823)

Philydor rufum (Vieillot, 1818)

Sclerurus scansor (Ménétries, 1835)

Synallaxis albescens Temminck, 1823*

Synallaxis frontalis Pelzeln, 1859 *

Synallaxis ruficapilla Vieillot, 1819

Synallaxis spixi Sclater, 1856

Xenops rutilans Temminck, 1821

ICTERIDAE

Cacicus chrysopterus (Vigors, 1825)

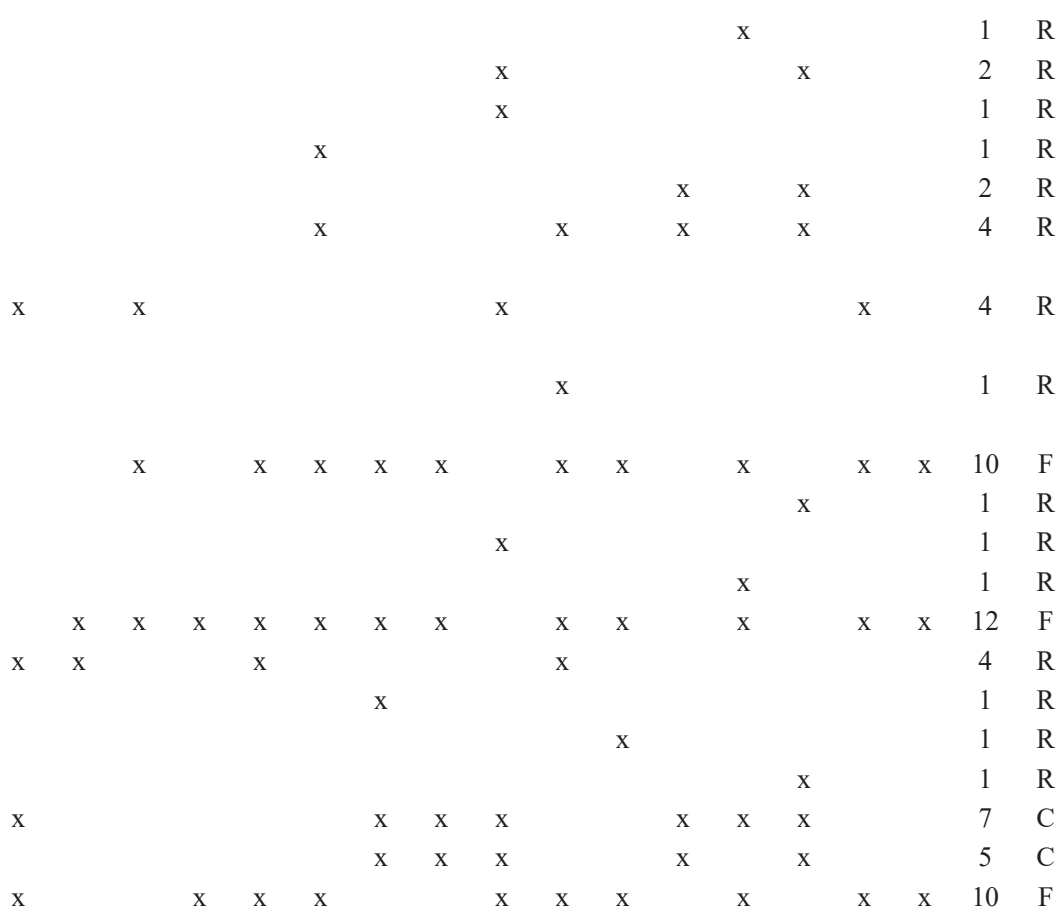


Appendix 3. Cont.

\begin{tabular}{|c|c|c|c|c|c|c|c|c|c|c|c|c|c|c|c|c|c|c|}
\hline \multirow{2}{*}{$\begin{array}{l}\text { Birds } \\
\text { FAMILY } \\
\text { Species }\end{array}$} & \multicolumn{16}{|c|}{ Localities } & \multirow[b]{2}{*}{ 完 } & \\
\hline & 毛 & ৩઼ & $\sum_{\circlearrowright}$ & $\underset{ن}{x}$ & $\stackrel{\overrightarrow{1}}{\Delta}$ & $\underset{\mid}{\stackrel{5}{x}}$ & 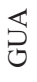 & $\underset{\Sigma}{\alpha}$ & そֶ & $\sum_{\Sigma}^{\infty}$ & $\stackrel{\infty}{\mathbb{L}}$ & ঠ. & $\stackrel{\wp}{\oslash}$ & $\underset{\sim}{\infty}$ & $\overrightarrow{\widetilde{\alpha}}$ & $\stackrel{\sim}{>}$ & & \\
\hline Molothrus bonariensis (Gmelin, 1789)* & & & & & & & & & & $\mathrm{x}$ & & & & & & & 1 & $\mathrm{R}$ \\
\hline Psarocolius decumanus (Pallas, 1769)* & & & & $\mathrm{x}$ & & & & & & & $\mathrm{x}$ & & & & & & 2 & $\mathrm{R}$ \\
\hline \multicolumn{19}{|l|}{ MIMIDAE } \\
\hline Mimus saturninus (Lichtenstein, 1823)* & & & & & & & & & $\mathrm{x}$ & & & & & & & & 1 & $\mathrm{R}$ \\
\hline \multicolumn{19}{|l|}{ PARULIDAE } \\
\hline Basileuterus culicivorus (Deppe, 1830) & $\mathrm{x}$ & & & $\mathrm{x}$ & & $\mathrm{x}$ & $\mathrm{x}$ & $\mathrm{x}$ & & $\mathrm{x}$ & $\mathrm{x}$ & $\mathrm{x}$ & $\mathrm{x}$ & & $\mathrm{x}$ & $\mathrm{x}$ & 11 & $\mathrm{~F}$ \\
\hline Basileuterus flaveolus (Baird, 1865) & & & $\mathrm{x}$ & & & & & & & & $\mathrm{x}$ & & & $\mathrm{x}$ & & & 3 & $\mathrm{R}$ \\
\hline Basileuterus hypoleucus Bonaparte, 1850 & & & $\mathrm{x}$ & & & & $\mathrm{x}$ & & $\mathrm{x}$ & & & $\mathrm{x}$ & & $\mathrm{x}$ & & & 5 & $\mathrm{C}$ \\
\hline Basileuterus leucoblepharus (Vieillot, 1817) & $\mathrm{x}$ & $\mathrm{x}$ & & & $\mathrm{x}$ & $\mathrm{x}$ & $\mathrm{x}$ & $\mathrm{x}$ & $\mathrm{x}$ & $\mathrm{x}$ & $\mathrm{x}$ & $\mathrm{x}$ & $\mathrm{x}$ & $\mathrm{x}$ & & $\mathrm{x}$ & 13 & $\mathrm{~F}$ \\
\hline \multicolumn{19}{|l|}{ PHALACROCORACIDAE } \\
\hline \multicolumn{19}{|l|}{ PICIDAE } \\
\hline Campephilus robustus (Lichtenstein, 1819)* & & & & & & & & $\mathrm{x}$ & & & & & & & & & 1 & $\mathrm{R}$ \\
\hline Celeus flavescens (Gmelin, 1788)* & & & & & & & $\mathrm{x}$ & & & & & & & & & & 1 & $\mathrm{R}$ \\
\hline Colaptes melanochloros (Gmelin, 1788)* & & & & & & & & & & & & & $\mathrm{x}$ & & & & 1 & $\mathrm{R}$ \\
\hline Dryocopus lineatus (Linnaeus, 1766)* & & & & & & & $\mathrm{x}$ & & $\mathrm{x}$ & & $\mathrm{x}$ & & & & & & 3 & $\mathrm{R}$ \\
\hline Piculus aurulentus (Temminck, 1823)* & & & & & & & & & & $\mathrm{x}$ & & & & & & & 1 & $\mathrm{R}$ \\
\hline Picumnus cirratus Temminck, 1825 & & & & & & & $\mathrm{x}$ & & $\mathrm{x}$ & & $\mathrm{x}$ & & $\mathrm{x}$ & $\mathrm{x}$ & $\mathrm{x}$ & $\mathrm{x}$ & 7 & $\mathrm{C}$ \\
\hline Veniliornis passerinus (Linnaeus, 1766)* & & & & & & & & & & & & $\mathrm{x}$ & & & & & 1 & $\mathrm{R}$ \\
\hline
\end{tabular}

\section{PIPRIDAE}

Chiroxiphia caudata (Shaw \& Nodder, 1793)

Manacus manacus (Linnaeus, 1766)

PSITTACIDAE

Aratinga auricapillus (Kuhl, 1820)*

Aratinga leucophthalma (Müller, 1776)*

Brotogeris tirica (Gmelin, 1788)*

RAMPHASTIDAE

Ramphastos dicolorus Linnaeus, 1766*

Ramphastos toco Müller, 1776*

STRIGIDAE

Pulsatrix koeniswaldiana (Bertoni \& Bertoni, 1901)*

Pulsatrix perspicillata (Latham, 1790)*

THAMNOPHILIDAE

Drymophila ferruginea (Temminck, 1822)*

Dysithamnus mentalis (Temminck, 1823)

Dysithamnus plumbeus (Wied, 1831)

Pyriglena leucoptera (Vieillot, 1818)

Thamnophilus caerulescens Vieillot, 1816

Thamnophilus torquatus Swainson, 1825*

\section{THRAUPIDAE}

Conirostrum speciosum (Temminck, 1824)*

Dacnis cayana (Linnaeus, 1766)*

Euphonia chlorotica (Linnaeus, 1766)*

Hemithraupis ruficapilla (Vieillot, 1818)*

Lanio melanops (Vieillot, 1818)

Pipraeidea melanonota (Vieillot, 1819)

Pyrrhocoma ruficeps (Strickland, 1844)

Stephanophorus diadematus (Temminck, 1823)*

Tachyphonus coronatus (Vieillot, 1822)

Tangara cayana (Linnaeus, 1766)

Tangara cyanocephala (Müller, 1776)*

Tangara desmaresti (Vieillot, 1819)*

Tangara ornata (Sparrman, 1789)* 
Appendix 3. Cont.

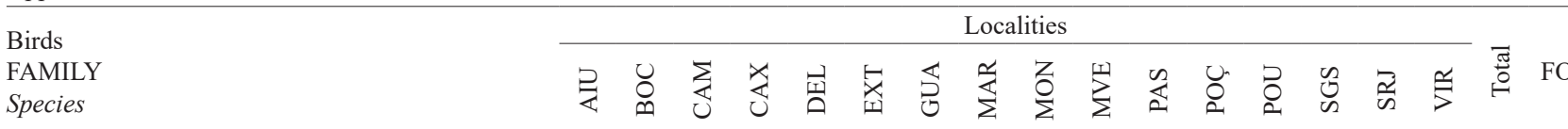

\section{TINAMIDAE}

Crypturellus obsoletus (Temminck, 1815)*

TROCHILIDAE

Amazilia láctea (Lesson, 1829)

Amazilia versicolor (Vieillot, 1818)

Clytolaema rubricauda (Boddaert, 1783)

Eupetomena macroura (Gmelin, 1788)*

Florisuga fusca (Vieillot, 1817)*

Leucochloris albicollis (Vieillot, 1818)

Phaethornis eurynome (Lesson, 1832)

Phaethornis pretrei (Lesson \& DeLattre, 1839)

Thalurania glaucopis (Gmelin, 1788)

TROGONIDAE

Trogon surrucura Vieillot, 1817*

TURDIDAE

Turdus albicollis Vieillot, 1818

Turdus amaurochalinus Cabanis, 1850

Turdus leucomelas Vieillot, 1818

Turdus leucops (Taczanowski, 1877)

Turdus rufiventris Vieillot, 1818

TYRANNIDAE

Attila rufus (Vieillot, 1819)

Camptostoma obsoletum (Temminck, 1824)*

Colonia colonus (Vieillot, 1818)*

Contopus cinereus (Spix, 1825)

Corythopis delalandi (Lesson, 1831)

Elaenia flavogaster (Thunberg, 1822)*

Elaenia obscura (D’Orbigny \& Lafresnaye, 1837)

Fluvicola nengeta (Linnaeus, 1766)*

Hemitriccus diops (Temminck, 1822)

Hemitriccus orbitatus (Wied, 1831)*

Knipolegus cyanirostris (Vieillot, 1818)

Lathrotriccus euleri (Cabanis, 1868)

Leptopogon amaurocephalus Tschudi, 1846

Megarynchus pitanguá (Linnaeus, 1766)*

Mionectes rufiventris Cabanis, 1846

Myiarchus tyrannulus (Müller, 1776)

Myiobius barbatus (Gmelin, 1789)

Myiodynastes maculatus (Müller, 1776)*

Myiopagis viridicata (Vieillot, 1817)

Myiophobus fasciatus (Müller, 1776)

Phyllomyias griseocapilla Sclater, 1861

Pitangus sulphuratus (Linnaeus, 1766)*

Platyrinchus mystaceus Vieillot, 1818

Todirostrum poliocephalum (Wied, 1831)*

Tolmomyias sulphurescens (Spix, 1825)

TYTONIDAE

Tyto alba (Scopoli, 1769)*

$\mathrm{x}$

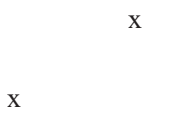

$\mathrm{x}$
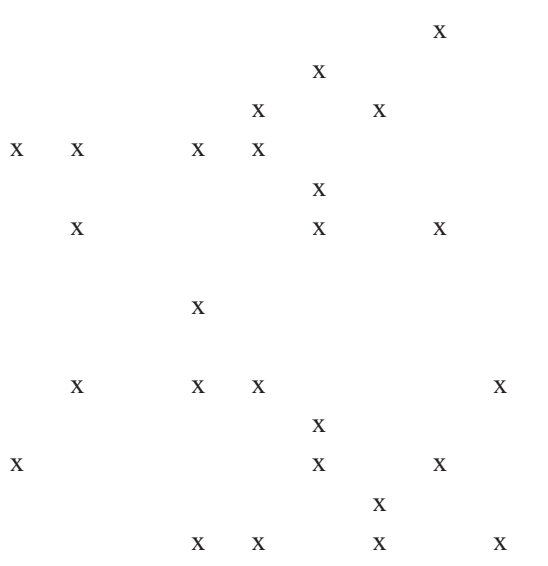

$\mathrm{x}$$$
x
$$

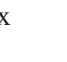

C

$R$

$\mathrm{R}$

$\mathrm{R}$

C

$\mathrm{x} \quad \mathrm{x} \quad 2 \quad \mathrm{R}$

$\begin{array}{llllll}\mathrm{X} & \mathrm{x} & \mathrm{x} & \mathrm{x} & 4 & \mathrm{R}\end{array}$

$\begin{array}{lllll}\mathrm{x} & \mathrm{x} & \mathrm{x} & \mathrm{R}\end{array}$

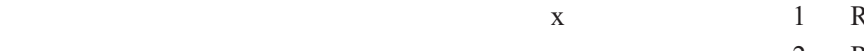

$\begin{array}{lll}\mathrm{x} & \mathrm{x} & \mathrm{R}\end{array}$

$\mathrm{x} \quad 1 \quad \mathrm{R}$

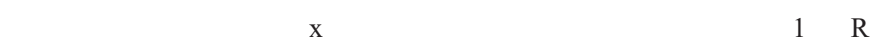

$\begin{array}{lll}x & x & R\end{array}$

$\mathrm{x} \quad 1 \quad \mathrm{R}$

$\begin{array}{lllllll}\mathrm{x} & \mathrm{x} & \mathrm{x} & \mathrm{x} & & 5 & \mathrm{C}\end{array}$

$\begin{array}{lllllllll}\mathrm{x} & \mathrm{x} & \mathrm{x} & \mathrm{x} & \mathrm{C} & & \end{array}$

$\begin{array}{llllll}x & x & 2 & R\end{array}$

$\begin{array}{lllllllllllllll}\mathrm{x} & \mathrm{x} & \mathrm{x} & \mathrm{x} & \mathrm{x} & \mathrm{x} & \mathrm{x} & \mathrm{x} & \mathrm{x} & \mathrm{x} & 10 & \mathrm{~F}\end{array}$

$\begin{array}{lllll}x & & 1 & R\end{array}$

$\begin{array}{llll}-x & R\end{array}$

x $\quad x \quad 2 \quad R$

$\begin{array}{llll}x & & R\end{array}$

$\mathrm{x}-1 \quad \mathrm{R}$

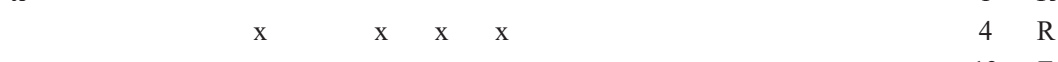

$\begin{array}{lllllllllllllllllllllllllll}\mathrm{x} & \mathrm{x} & \mathrm{x} & \mathrm{x} & \mathrm{x} & \mathrm{x} & \mathrm{x} & \mathrm{x} & \mathrm{x} & \mathrm{x} & \mathrm{x} & \mathrm{x} & \mathrm{x} & 13 & \mathrm{~F}\end{array}$

$\begin{array}{lllll}\mathrm{x} & \mathrm{X} & \mathrm{X} & \mathrm{R}\end{array}$

VIREONIDAE

Cyclarhis gujanensis (Gmelin, 1789)

Vireo olivaceus (Linnaeus, 1766)*

\begin{tabular}{lllllllllllllllllll}
\hline Total & 24 & 16 & 15 & 16 & 25 & 31 & 44 & 28 & 45 & 26 & 33 & 38 & 40 & 34 & 23 & 20 &
\end{tabular}


Appendix 4. Species of primates recorded in the 16 localities sampled in Minas Gerais, Brazil, and their respective frequency of occurrence (FO): R (Rare); C (Common); and F (Frequent) (AIU, Aiuruoca; BOC, Bocaina de Minas; CAM, Camanducaia; CAX, Caxambu; DEL, Delfim Moreira; EXT, Extrema; GUA, Guaxupé; MAR, Maria da Fé; MON, Monte Belo; MVE, Monte Verde; PAS, Passa Quatro; POÇ, Poços de Caldas; POU, Pouso Alegre; SGS, São Gonçalo do Sapucaí; SRJ, Santa Rita de Jacutinga; VIR, Virgínia).

\begin{tabular}{|c|c|c|c|c|c|c|c|c|c|c|c|c|c|c|c|c|c|c|}
\hline \multirow{2}{*}{$\begin{array}{l}\text { Primates } \\
\text { FAMILY } \\
\text { Species }\end{array}$} & \multicolumn{16}{|c|}{ Localities } & \multirow[b]{2}{*}{ Total } & \multirow[b]{2}{*}{$\mathrm{FO}$} \\
\hline & そ & ๖ֶ & $\sum_{\circlearrowright}$ & 这 & 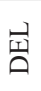 & 离 & 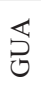 & $\underset{\Sigma}{\longleftarrow}$ & $\stackrel{\text { Z }}{\text { Z }}$ & $\sum^{1}$ & $\sum_{\infty}^{\infty}$ & 仓 & 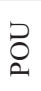 & $\underset{\sim}{\mathscr{N}}$ & $\frac{\vec{\alpha}}{\sim}$ & $\stackrel{\oiiint}{\lessgtr}$ & & \\
\hline ATELIDAE & & & & & & & & & & & & & & & & & & \\
\hline $\begin{array}{l}\text { Alouatta guariba clamitans (Humboldt, 1812) } \\
\text { CALLITRICHIDAE }\end{array}$ & $\mathrm{x}$ & $\mathrm{x}$ & & & $\mathrm{x}$ & $\mathrm{x}$ & & $\mathrm{x}$ & & $\mathrm{x}$ & $\mathrm{x}$ & & $\mathrm{x}$ & & $\mathrm{x}$ & & 9 & $\mathrm{~F}$ \\
\hline Callithrix aurita (E. Geoffroy in Humboldt, 1812) & & & & $\mathrm{x}$ & & $\mathrm{x}$ & & & & & $\mathrm{x}$ & $\mathrm{x}$ & $\mathrm{x}$ & & $\mathrm{x}$ & $\mathrm{x}$ & 7 & $\mathrm{C}$ \\
\hline $\begin{array}{l}\text { Callithrix penicillata (E. Geoffroy, 1812) ** } \\
\text { CEBIDAE }\end{array}$ & $\mathrm{x}$ & $\mathrm{x}$ & & $\mathrm{x}$ & & & $\mathrm{x}$ & & & & $\mathrm{x}$ & & & & & & 5 & $\mathrm{C}$ \\
\hline $\begin{array}{l}\text { Sapajus nigritus (Goldfuss, 1809) } \\
\text { PITHECIIDAE }\end{array}$ & & & & $\mathrm{x}$ & $\mathrm{x}$ & & $\mathrm{x}$ & & $\mathrm{x}$ & & & & $\mathrm{x}$ & & & & 5 & $\mathrm{C}$ \\
\hline Callicebus nigrifrons (Spix, 1823) & $\mathrm{x}$ & $\mathrm{x}$ & $\mathrm{x}$ & $\mathrm{x}$ & $\mathrm{x}$ & $\mathrm{x}$ & $\mathrm{X}$ & $\mathrm{X}$ & $\mathrm{X}$ & $\mathrm{X}$ & $\mathrm{X}$ & $\mathrm{X}$ & $\mathrm{X}$ & $\mathrm{X}$ & $\mathrm{X}$ & $\mathrm{X}$ & 16 & $\mathrm{~F}$ \\
\hline Total & 3 & 3 & 1 & 4 & 3 & 3 & 3 & 2 & 2 & 2 & 4 & 2 & 4 & 1 & 3 & 2 & & \\
\hline
\end{tabular}

